
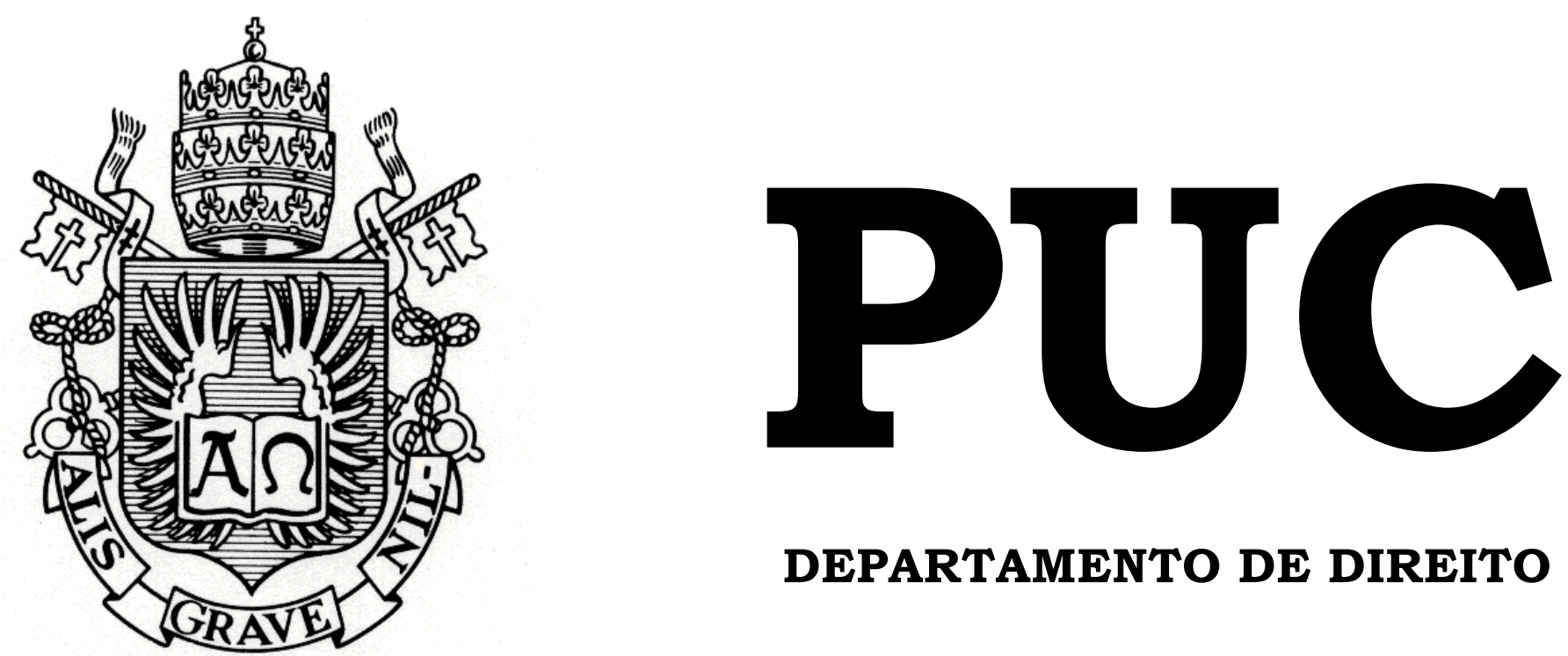

DEPARTAMENTO DE DIREITO

\title{
O Controle Parlamentar das Atividades de Inteligência no Brasil
}

por

MARINA MARANDINO

ORIENTADOR: ADRIANO PILATTI

2014.2

PONTIFÍCIA UNIVERSIDADE CATÓLICA DO RIO DE JANEIRO

RUA MARQUÊS DE SÃO VICENTE, 225 - CEP 22453-900

RIO DE JANEIRO - BRASIL 


\section{O Controle Parlamentar das Atividades de Inteligência no Brasil}

por

MARINA MARANDINO

Monografia apresentada ao Departamento de Direito da Pontificia Universidade Católica do Rio de Janeiro (PUC-Rio) como requisito parcial para obtenção do título de Bacharel em Direito.

Orientador: Adriano Pilatti 


\section{Agradecimentos}

Aos meus pais, minha família e amigos, pelo apoio constante.

À Dona Liza, pela eterna paciência.

Ao Professor Adriano Pilatti por sua orientação e incentivo.

A todos os professores que participaram da minha formação, e em especial à professora Telma Lage.

A todos que, de alguma forma, me auxiliaram nessa jornada. 


\section{Resumo}

Em 1999, a Lei no 9.883 marcou o início de um período de reformas na inteligência brasileira ao criar o Sistema Brasileiro de Inteligência (SISBIN) e a Agência Brasileira de Inteligência (ABIN). A criação destas novas estruturas, contudo, não garante necessariamente a ausência de abusos e ilegalidades, ainda que somada à legislação posterior pertinente à mesma temática.

Mesmo em democracias consolidadas, não são raros os escândalos envolvendo abusos cometidos por agências de inteligência. Em novas democracias, instituídas após regimes totalitários, o uso histórico da inteligência como mecanismo de manutenção do poder gera desafios ainda maiores.

Nesse sentido, merece destaque a questão do controle e, em especial, o controle parlamentar. Recentemente foi aprovada nova Resolução do Congresso Nacional regulamentando as atividades da Comissão de Controle das Atividades de Inteligência (CCAI - Resolução $\mathrm{n}^{0} 2$ de 2013-CN). O envolvimento do legislativo na fiscalização da inteligência é crucial para a legitimidade e accountability democrática dessa atividade. Dados os riscos a ela inerentes e a experiência histórica brasileira, é fundamental avaliar se a presente base legal possibilita um controle parlamentar eficaz e apto a contribuir para o funcionamento democrático das estruturas de segurança.

\section{Palavras Chave}

Inteligência, Agências de inteligência, ABIN - Agência de Inteligência Brasileira, SISBIN - Sistema de Inteligência Brasileiro, Controle Parlamentar, CCAI - Comissão Mista de Controle das Atividades de Inteligência. 


\section{Sumário}

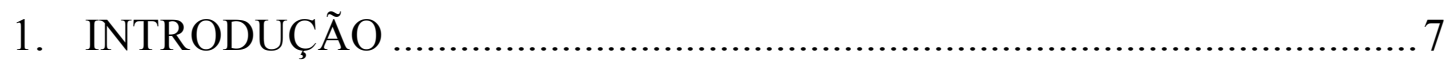

2. CONSIDERAÇÕES INICIAIS SOBRE A ATIVIDADE DE

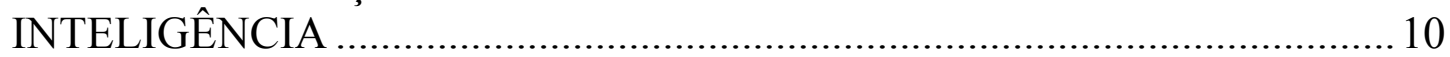

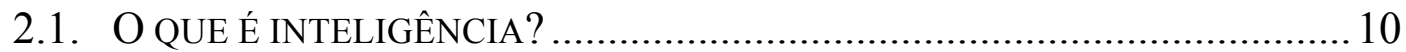

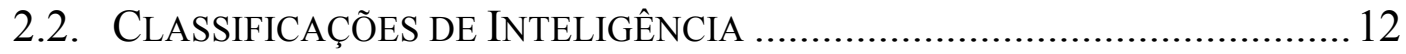

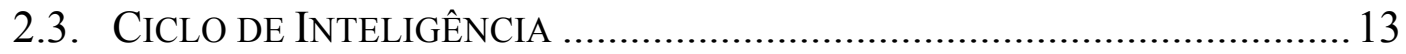

2.4. INTELIGÊNCIA E DEMOCRACIA: O CASO BRASILEIRO ……..................... 14

2.5. SISBIN E ABIN: A REESTRUTURAÇÃO DA INTELIGÊNCIA

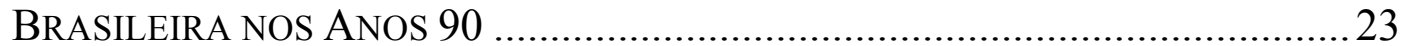

3. O CONTROLE PARLAMENTAR DAS ATIVIDADES DE

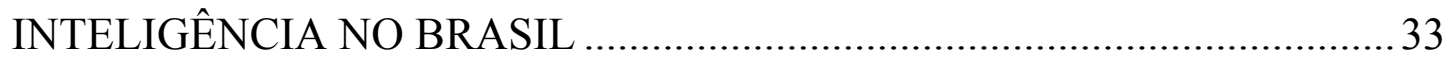

3.1. OBSERVAÇÕES INICIAIS SOBRE CONTROLE ……..................................33

3.2. POR QUE CONTROLAR AS ATIVIDADES DE INTELIGÊNCIA? ......................34

3.3. CONTEÚDO DO CONTROLE DA INTELIGÊNCIA .......................................... 36

3.4. FORMAS DE CONTROLE DA INTELIGÊNCIA ……..................................... 37

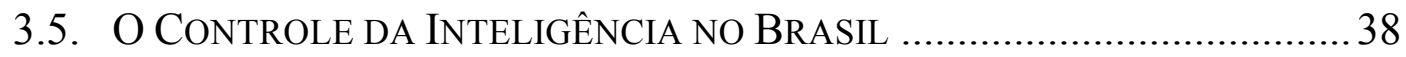

3.6. Controle E O Poder LegiSLATIVO ..................................................42

3.7. O CONTROLE DAS ATIVIDADES DE INTELIGÊNCIA PELO

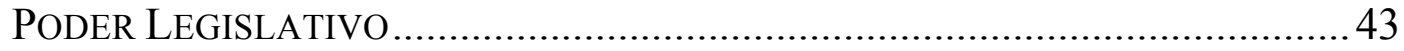

3.8. OS DESAFIOS DO CONTROLE PARLAMENTAR DA INTELIGÊNCIA .............45

3.9. O CONTROLE PARLAMENTAR DA INTELIGÊNCIA

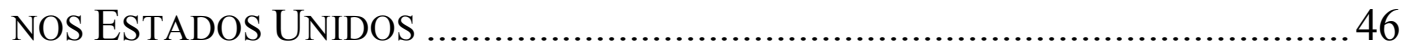

3.10. O CONTROLE PARLAMENTAR DA INTELIGÊNCIA NO BRASIL ...............48

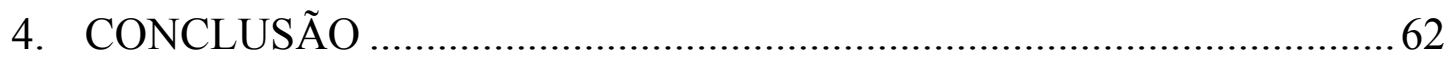

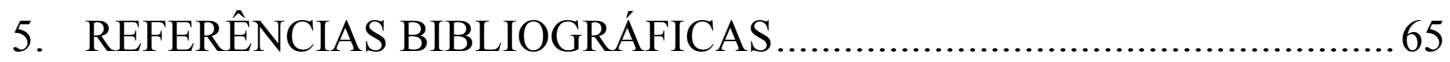


Lista de Abreviações

\begin{tabular}{|c|c|}
\hline ABIN & Agência Brasileira de Inteligência \\
\hline ANATEL & Agência Nacional de Telecomunicações \\
\hline BOSS & South African Bureau for State Security \\
\hline CCAI & $\begin{array}{l}\text { Comissão Mista de Controle das Atividades de } \\
\text { Inteligência }\end{array}$ \\
\hline CENIMAR & Centro de Informações da Marinha \\
\hline CGU & Controladoria-Geral da União \\
\hline CIA & Central Intelligence Agency \\
\hline CIE & Centro de Informações do Exército \\
\hline CISA & Centro de Informações de Segurança da Aeronáutica \\
\hline CREDEN & Câmara de Relações Exteriores e Defesa Nacional \\
\hline CSIS & Canadian Security Intelligence Service \\
\hline DCAF & $\begin{array}{l}\text { Geneva Centre for the Democratic Control of Armed } \\
\text { Forces }\end{array}$ \\
\hline DI & Departamento de Inteligência \\
\hline DINA & Dirección de Inteligencia Nacional \\
\hline ESG & Escola Superior de Guerra \\
\hline FBI & Federal Bureau of Investigation \\
\hline GSI & Gabinete de Segurança Institucional \\
\hline PNI & Política Nacional de Inteligência \\
\hline
\end{tabular}




\begin{tabular}{|l|l|}
\hline SAE & Secretaria de Assuntos Estratégicos \\
\hline SAVAK & Organização de Segurança e Inteligência Nacional do Irã \\
\hline SISBIN & Sistema Brasileiro de Inteligência \\
\hline SISNI & Sistema Nacional de Informações \\
\hline SISP & Sistema Integrado de Segurança Pública \\
\hline SNI & Serviço Nacional de Informações \\
\hline TCU & Tribunal de Contas da União \\
\hline
\end{tabular}




\section{Introdução}

Pensar o controle da atividade de inteligência pressupõe duas bases. A primeira exige partir da formulação de um juízo acerca da necessidade dos serviços estatais de inteligência como meio de garantir segurança aos cidadãos - em outras palavras, perguntar se são necessários, e qual o seu papel. A segunda demanda a compreensão prévia dos riscos apresentados pela atividade de inteligência a aspecto essenciais ao sistema democrático (CEPIK, 2005, p. 68; UGARTE, 2002).

O trabalho se iniciará, portanto, com a discussão desses fundamentos, no Capítulo "Considerações Iniciais sobre a Atividade de Inteligência". A partir de doutrina nacional e internacional, busca estabelecer o que se entende por inteligência, e qual o seu papel na estrutura de segurança dos Estados Democráticos.

Em seguida, o Capítulo "O Controle Parlamentar das Atividades de Inteligência do Brasil" trata do tema do controle das atividades de inteligência, buscando estabelecer suas finalidades, objetivos e desafios. Discute, ainda, as diferentes formas de controle da inteligência e como elas são aplicadas no Brasil e no Direito Comparado. Em seguida, aborda a questão central do trabalho: o controle parlamentar da inteligência. $\mathrm{O}$ objetivo, aqui, é compreender esse controle e seus desafios, e aplicar parâmetros de análise estabelecidos pela doutrina para avaliar a legislação que o regulamenta no Brasil, e verificar se a estrutura legal da inteligência no país é capaz de dar ensejo a um controle parlamentar eficaz.

Até a década de 1970, qualquer tentativa de estabelecer estruturas de controle para as agências de inteligência seria considerada ingênua e perigosa, mesmo em países de longa tradição democrática. Desde então, uma série de escândalos envolvendo abusos por parte de agentes de inteligência resultou na 
busca por elaborar sistemas de controle capazes de proteger as liberdades civis (GILL \& PHYTHIAN, 2012, p. 171).

Mesmo após 40 anos de esforços, contudo, essa forma de atividade permanece difícil de compatibilizar com a publicidade dos atos do governo necessária a um sistema republicano e democrático (BRUNEAU \& CRISTIANA, 2010, p. 757; UGARTE, 2002).

Em regimes autoritários, o objetivo primário das agências de inteligência é a preservação do regime e a supressão da oposição (GILL \& PHYTHIAN, 2012, p. 173). Na ditadura militar brasileira essa função foi desempenhada principalmente pelo Serviço Nacional de Informações (SNI), que tinha por finalidade "superintender e coordenar, em todo o território nacional, as atividades de informação e contra informação, em particular as que interessem à Segurança Nacional" (Lei no 4.341 de 13 de junho de 1964, art. $2^{\circ}$ ).

O SNI era dotado de elasticidade funcional que lhe permitia penetrar sistematicamente em todos os níveis do governo (CEPIK \& ANTUNES, 2001). Tornou-se um poder político quase tão importante quanto o Executivo, e não era "obrigado a publicar informações, revelar sua estrutura organizacional ou discutir o funcionamento de suas agências" (MOREIRA ALVES, 1985, p. 73).

O SNI foi extinto em 1990, após o fim do regime militar. O esvaziamento subsequente das estruturas de inteligência não significou que o alicerce sobre o qual operavam tenha sido modificado. Na prática, a pouca importância dada ao setor permitia que seus agentes operassem sem regulamentação (CEPIK \& ANTUNES, 2001, p. 17).

Em 1999, a Lei no 9.883 marcou o início de um período de reformas na inteligência brasileira ao criar o Sistema Brasileiro de Inteligência (SISBIN) e a Agência Brasileira de Inteligência (ABIN). A criação destas novas estruturas, 
contudo, não garante necessariamente a ausência de abusos e ilegalidades, ainda que somada à legislação posterior pertinente à mesma temática.

Mesmo em democracias consolidadas, não são raros os escândalos envolvendo abusos cometidos por agências de inteligência. Em novas democracias, instituídas após regimes totalitários, o uso histórico da inteligência como mecanismo de manutenção do poder gera desafios ainda maiores. A estrutura de repressão interna e o ideário que a impulsiona são, com frequência, difíceis de desmantelar (BRUNEAU \& CRISTIANA, 2010; CEPIK \& ANTUNES, 2001).

Nesse sentido, merece destaque a questão do controle e, em especial, o controle parlamentar. Recentemente foi aprovada nova Resolução do Congresso Nacional regulamentando as atividades da Comissão de Controle das Atividades de Inteligência (CCAI - Resolução ${ }^{0} 2$ de 2013-CN). O envolvimento do legislativo na fiscalização da inteligência é crucial para a legitimidade e accountability democrática dessa atividade (BORN \& LEIGH, 2005, p. 77). Dados os riscos a ela inerentes e a experiência histórica brasileira, é fundamental avaliar se a presente base legal possibilita um controle parlamentar eficaz e apto a contribuir para o funcionamento democrático das estruturas de segurança. 


\section{Considerações Iniciais sobre a Atividade de Inteligência}

\subsection{O que é inteligência?}

Ao falar sobre controle, é imperativo determinar o que se pretende controlar. O termo "inteligência" é utilizado para descrever sistemas de informações, sejam eles governamentais ou não. O uso de "business intelligence" e "inteligência competitiva", por exemplo, é hoje frequente no setor privado, com o objetivo de obter vantagens em relação a outros concorrentes no mercado. No âmbito estatal, contudo, "inteligência" tem significado mais restrito, que está geralmente associado a temas específicos e instituições especializadas (LOWENTHAL, 2012, p. 1). Interessante destacar que o termo "inteligência" foi adotado no Brasil a partir dos anos 90. Antes se fazia uso da terminologia "informações" que, assim como a expressão "segurança nacional", ficou demasiado associada ao regime militar, e foi substituída por razões políticas (GONÇALVES, 2013, p. 14)

Em obra clássica, Sherman Kent divide a inteligência em três diferentes facetas (HERMAN, 1996, p. 2): (a) como produto, ou seja, informação resultante do processo de produção de conhecimento; (b) como processo ou atividade, uma forma de produção de conhecimento que possui meios e metodologia próprios; e (c) como organização, instituições e estruturas cujo objetivo primordial é obter informações e produzir conhecimento de inteligência.

A legislação brasileira atual traz definição de inteligência no art. $1^{\circ}, \S 2^{\circ}$ da Lei $n^{\circ}$ 9.883/1999:

“Art. $1^{\circ}$, $\S 2^{\circ}$ : Para os efeitos de aplicação desta Lei, entende-se como inteligência a atividade que objetiva a obtenção, análise e disseminação de conhecimentos dentro e fora do território nacional sobre fatos e situações de imediata ou potencial influência sobre o processo decisório e a ação governamental e sobre a salvaguarda e a segurança da sociedade e do Estado." 
Nota-se, aqui, que o legislador restringiu a definição a apenas um dos aspectos definidos por Kent: a inteligência como processo ou atividade. $\mathrm{O} \S 3^{\circ}$ do mesmo artigo segue lógica similar, e define a contra inteligência como " $a$ atividade que objetiva neutralizar a inteligência adversa". Para Joanisval Gonçalves,

"essa percepção do legislador pode estar relacionada às deficiências no arcabouço legal pátrio no que concerne à inteligência como produto e organização, inclusive com lacunas prejudiciais às organizações e seus servidores e deficiência normativa em termos de proteção ao conhecimento" (GONÇALVES, 2013, p. 21).

Priscila Brandão Antunes, por sua vez, critica a definição de inteligência por ser excessivamente aberta. A referência a "fatos e situações de imediata ou potencial influência sobre o processo decisório" permite que a inteligência governamental inclua virtualmente qualquer tema. Segunda a autora:

"Em tese, a conceituação apresentada significa a busca da onisciência na condução dos assuntos do governo. Mantem-se a acepção comum de igualar inteligência ao processamento de informações para o processo decisório. Diferente do que é proposto pelo modelo típico ocidental, a atividade foi confundida com a coleta de todas e quaisquer informações que possam auxiliar o governo em suas decisões (econômicas, politicas, sociais etc.). De acordo com este modelo, teria sido necessário reduzir o enfoque dado à atividade de inteligência, que possui associações historicamente determinadas com relações internacionais, defesa, segurança nacional e segredo". (ANTUNES, 2001, p.168)

Ela critica, ainda, a definição de contra inteligência, também sujeita a interpretações amplas. Nesse sentido, esclarece que, no padrão típico ocidental, contra inteligência se resume à neutralização de espionagem estrangeira e proteção aos segredos do país. (ANTUNES, 2001, p.169)

Importante ressaltar, ainda, que a definição de inteligência é profundamente influenciada pelo conceito de segurança (UGARTE, 2002). Segundo Gill e Phytian, um dos fatores que devem figurar em qualquer definição de inteligência é sua base na segurança (GILL \& PHYTHIAN, 2012, p. 18). A legislação brasileira atual deixa clara esta associação no trecho 
"sobre fatos e situações de imediata ou potencial influência sobre [...] a salvaguarda e a segurança da sociedade e do Estado".

Definir o que constitui ou não uma ameaça à segurança, contudo, não é tarefa simples. Em países centrais, o conceito clássico de segurança engloba ameaças representadas por Estados estrangeiros, relacionadas à defesa e às relações internacionais, ou até mesmo da economia. Na América Latina, os termos segurança nacional e defesa nacional adquiriram grande amplitude conceitual, referida principalmente ao âmbito interno e à defesa da ordem política, e expandiram-se de forma a incluir virtualmente a totalidade da política de seus países (UGARTE, 2001, 2002). Como se verá a seguir, este enfoque interno foi marcante característica da atuação da inteligência brasileira durante a ditadura militar, e permanece presente até os dias de hoje.

\subsection{Classificações de Inteligência}

São várias as formas de classificar as atividades de inteligência. Em geral, são classificações baseadas em seu objeto (militar, policial, financeira, fiscal, estratégica, etc.) ou em seu âmbito de atuação (interna, externa).

A inteligência de Estado está associada ao processo de produção de conhecimentos que tem por escopo a segurança do Estado e da sociedade, e que são utilizados no processo decisório da mais alta esfera de governo (GONÇALVES, 2013, p. 47). Subdivide-se em externa e interna.

Inteligência externa é aquela relacionada à segurança externa, ou seja, à identificação de riscos e ameaças provenientes de pessoas, grupos ou Estados estrangeiros, bem como organizações internacionais e transnacionais. Está relacionada à política externa de um país (GONÇALVES, 2013, p. 48)

Inteligência interna ou doméstica relaciona-se a informações voltadas para a segurança do Estado e da sociedade contra ameaças no interior do território nacional (GONÇALVES, 2013, p. 50). De fato, um governo não deve 
se preocupar apenas com ameaças internas (como uma invasão militar), mas também com ameaças a sua existência ou capacidade de governar que surjam de indivíduos ou grupos dentro do território nacional. No entanto, a percepção do que exatamente representa ou não uma ameaça interna depende fundamentalmente da natureza de um regime e governo. Quando um grupo detém o monopólio do poder, provavelmente irá considerar toda a oposição política uma ameaça à segurança, e direcionar seu aparato de inteligência contra ela. Por outro lado, um sistema democrático implica na ideia de que a oposição política não é uma ameaça à segurança interna, e portanto não poderia ser um alvo de inteligência (SCHULSKY \& SMITH, 2002, p. 4).

\subsection{Ciclo de Inteligência}

O ciclo da inteligência é uma análise teórica das várias atividades implicadas na atuação dos serviços de inteligência, ou "a descrição de um processo no qual as informações coletadas principalmente pelas agências de inteligência são postas à disposição de seus usuários" (ANTUNES, p. 29). Compreende tradicionalmente os seguintes estágios:

- Planejamento e direcionamento

- Coleta

- Processamento

- Análise e produção

- Disseminação (GILL \& PHYTHIAN, 2012, p. 12)

Nota-se, aqui, que o artigo $3^{\circ}$ da Lei $\mathrm{n}^{\circ} 9.883$ faz referência a apenas parte do ciclo ("obtenção, análise e disseminação"). Contudo, a Resolução n 2 de 2013-CN, que em 2013 alterou o funcionamento da CCAI, esclarece que a comissão exercerá controle sobre todo o ciclo da inteligência: 
Art. $2^{\circ} \S 2^{\circ} \mathrm{O}$ controle da atividade de inteligência realizado pelo Congresso Nacional compreende as atividades exercidas pelos órgãos componentes do SISBIN em todo o ciclo da inteligência, entre as quais as de reunião, por coleta ou busca, análise de informações, produção de conhecimento, e difusão, bem como a função de contrainteligência e quaisquer operações a elas relacionadas.

\title{
2.4. Inteligência e Democracia: o Caso Brasileiro
}

O uso de aparatos de inteligência como forma de manutenção do poder é característica histórica de regimes não democráticos:

\begin{abstract}
"Reconhecidamente, regimes não democráticos (em todas as suas formas autoritários, totalitários etc.), criam e usam agências de inteligência para garantir a "sobrevivência" do regime. [...] Usam seus aparatos de inteligência (conhecidos como 'polícias políticas') para controlar, intimidar, manipular, abusar e oprimir 'inimigos ideológicos' reais ou imaginários, tanto domesticamente quanto no exterior, sem respeito por direitos humanos e liberdades individuais, e sem prestar contas democraticamente para o povo, mas apenas para uns poucos líderes políticos. [..] Com o tempo, conforme os regimes tendem a confiar cada vez mais nas agências de inteligência, seu poder e tamanho aumentam, e elas se transformam de 'polícias políticas' em 'estados de segurança independentes'. Estados de segurança independentes ganham maior autonomia em relação ao regime e isolamento de qualquer escrutínio. Tais aparatos de inteligência existiram no Brasil (SNI), Iran (SAVAK), Chile (DINA) e África do Sul (BOSS)." "l
\end{abstract}

1 "Admittedly, nondemocratic regimes (in all their forms - authoritarian, totalitarian, etc.), create and use intelligence agencies to ensure the "survival" of the regime. [...] They use their intelligence appatatuses (known as "political polices") to control, intimidate, manipulate, abuse, and oppress real and/or imaginary 'ideological enemies', both domestically and abroad, with no respect for human rights and liberties, and without being democratically accountable to the people, but rather to a few political leaders. [...] With time, as the regimes tend to increasingly rely on the intelligence agencies, their power and size heighten, and they shift from 'political polices' to 'independent security states'. Independent security states gain incremental autonomy from regime and insulation from any scrutinity. Such intelligence apparatuses existed in Brazil (SNI), Iran (SAVAK), Chile (DINA), and South Africa (BOSS)." (BRUNEAU; CRISTIANA, 2010). No mesmo sentido, "In postauthoritarian societies there are often strong memories of security and intelligence services endowed with broad mandates and sweeping powers used to protect dictatorial regimes against rebellions from their own people. Services were used by such regimes to suppress political opposition, to prevent any kind of demonstration and to eliminate leaders of labour unions, the media, political parties and other civil society organisations. In doing so, the services intervened deeply in the political and daily life of the citizens." (BORN; LEIGH, 2005, p. 33) 
Nesses casos, a preocupação com o combate à oposição política costuma gerar agências poderosas e voltadas principalmente para a inteligência interna. Durante a ditadura militar brasileira, o Sistema Nacional de Informações (SNI) foi a agência de inteligência que assumiu esse papel de forte repressão ideológica. Segundo a o Art. $2^{\circ}$ da Lei $n^{\circ} 4.341 / 64$, este órgão tinha "por finalidade superintender e coordenar, em todo o território nacional, as atividades de informação e contra informação, em particular as que interessem à Segurança Nacional’. O SNI era a cabeça de uma grande rede de inteligência à disposição do governo militar, que incluía os serviços de inteligência das Forças Armadas (o CENIMAR, na Marinha, o CIE no Exército e o CISA na Aeronáutica) (CEPIK \& ANTUNES, 2001, p. 7). Atuava dentro da lógica do "inimigo interno", e sua criação representou o início da aplicação legal da Doutrina de Segurança Nacional (ALVES, 1985, pp. 72-74).

A Doutrina de Segurança Nacional inspirou-se em práticas internacionais (especialmente dos Estados Unidos), mas adquiriu contornos diferenciados no Brasil e na América Latina. Aqui, os conceitos de segurança e defesa abarcaram elementos de natureza política e se caracterizam por notável amplitude, uma tendência ainda hoje que permanece presente. A defesa nacional e a segurança interior se confundiram e expandiram até englobar virtualmente toda a política dos países da região (UGARTE, 2001, p. 1).

O Decreto-Lei $\mathrm{n}^{\circ}$ 314, de 13 de março de 1967, incorporou oficialmente a Doutrina da Segurança Nacional ao ordenamento jurídico brasileiro. Em seu artigo $3^{\circ}$, deixa claro o largo escopo do termo "segurança nacional", estabelecendo que ele "compreende, essencialmente, medidas destinadas à preservação da segurança externa e interna, inclusive a prevenção e repressão da guerra psicológica adversa e da guerra revolucionária ou subversiva”. O mesmo artigo traz, ainda, o conceito de guerra revolucionária, que seria " $o$ conflito interno, geralmente inspirado em uma ideologia ou auxiliado do 
exterior, que visa à conquista subversiva do poder pelo controle progressivo da Nação"

Conforme leciona Maria Helena Moreira Alves, o Manual Básico da Escola Superior de Guerra publicado em 1976 destacava que o Terceiro Mundo não devia preocupar-se tanto com a guerra limitada ou total quanto com a guerra revolucionária. Esta não envolvia necessariamente o emprego da força armada, e podia ser travada em "fronteiras ideológicas" (ALVES, 1985, pp. 37-38). Essa ideia foi fundamental para o conceito de "inimigo interno", que pautava os objetivos do SNI. Para a autora,

"Quaisquer que tenham sido as intenções iniciais, a dinâmica do sistema e a busca de segurança absoluta efetivamente transformaram o SNI numa agência de espionagem dos cidadãos; numa situação em que se verificava impossivel isolar o 'inimigo interno', todos eram suspeitos.

[...]

Na prática, o SNI tornou-se um poder político de facto quase tão importante quanto o próprio executivo." (ALVES, 1985, p. 72)

Embora violações a direitos civis e humanos tenham começado a ser praticadas desde sua criação, a expansão do SNI no final dos anos 1960, associada à criação do CIE e do CISA e à reorientação doutrinária da CENIMAR, foi parte do início do período mais repressor do regime militar. A comunidade de informações se tornou uma rede complexa e inserida nos vários níveis da organização social (ANTUNES, 2001, pp. 76, 85).

O SNI não era sujeito a publicar informações, revelar sua estrutura funcional ou discutir o funcionamento de suas agências, e respondia apenas ao Presidente da República - sobre o qual, na prática, exercia considerável pressão (ALVES, 1985, pp. 73). Também não era obrigado a revelar ao Congresso informações sobre sua organização, operações e pessoal (CEPIK \& ANTUNES, 2001, p. 7). Era composto por uma agência central e agências 
regionais, as quais poderiam ser criadas conforme necessário ${ }^{2}$. Sua estrutura era, portanto, dotada de grande flexibilidade, que o tornava capaz de se adaptar às novas conjunturas e transformar-se em verdadeiro complexo de informações (ANTUNES, p. 53).

Resta claro, portanto, que a atuação do SNI se caracterizava por alto grau de autonomia e elasticidade funcional. Sua extinção ocorreu durante o governo Collor em 1990, mas não representou o fim das práticas de segurança e inteligência tradicionais das forças armadas ou da polícia (CEPIK \& ANTUNES, 2001, p. 13).

Após extinguir o SNI, Collor criou a Secretaria de Assuntos Estratégicos (SAE) e subordinou a mesma ao Departamento de Inteligência (DI). Embora estivesse sob responsabilidade da SAE, a atividade civil de inteligência ficou em segundo plano. Os funcionários do DI recebiam pouca orientação quanto a suas funções, mas tinham grande liberdade de atuação (ANTUNES, 2001, p. 109).

O fim do SNI inaugurou uma nova fase da inteligência brasileira, que passava a ter por desafio adequar-se a um regime democrático. Aqui, torna-se necessário expandir o enfoque para além do Brasil e da América Latina, e levantar um questionamento de natureza internacional: qual é, afinal, a função da inteligência governamental numa democracia?

A presença de agências de inteligência é uma constante no cenário internacional, e virtualmente todos os países as utilizam de alguma forma. Em conjunto com as forças armadas e as polícias, elas formam "o núcleo coercitivo do Estado contemporâneo" (CEPIK, 2002, p.1).

As primeiras organizações profissionais de inteligência surgem no contexto da consolidação dos Estados nacionais, em resposta à necessidade dos

\footnotetext{
2 “Art. $4^{\circ}$ O SNI compreende:

- uma Chefia com sede no Distrito Federal;

- uma Agência Central também com sede no Distrito Federal;

- Agências Regionais, tantas quantas necessárias, com sede em capitais dos Estados ou cidades

importantes." (Regulamento do SNI, aprovado pelo Decreto 55.194 de 20 de dezembro de 1964)
} 
governantes de reduzir os custos de obtenção de informações. Os serviços de inteligência modernos tinham ainda funções relacionadas ao uso dessas informações para a dominação e a maximização do poder do Estado. Nascem, portanto, com uma dupla natureza, informacional e coercitiva, que ainda hoje caracteriza os sistemas nacionais de inteligência. Sua evolução, porém, é marcada por descontinuidades históricas, que deram origem a grande diversidade funcional e organizacional. Atualmente os serviços de inteligência têm função predominantemente informacional, com alguns aspectos da função diretamente coercitiva (CEPIK, 2002, pp. 4-6).

Para Mark Lowenthal, as agências de inteligência atuais existem por quatro razões principais: para evitar surpresa estratégica; proporcionar conhecimentos a longo prazo; para apoiar o processo político; e para manter o sigilo de informações, necessidades e métodos (LOWENTHAL, 2012, p. 2).

Para entender as funções citadas pelo autor, é importante destacar sua origem norte-americana. Refere-se ao modelo típico ocidental de inteligência, que se limita a questões relativas a relações internacionais, defesa, segurança nacional e segredo (ANTUNES, 2001, p. 168) - sendo que, como já foi discutido, segurança e defesa abarcam uma área de atuação bem mais restrita do que na América Latina. Conforme leciona Priscila Brandão Antunes, a atividade de inteligência deveria possuir âmbito de atuação bem mais restrito do que o definido pela legislação brasileira:

\footnotetext{
"Em primeiro lugar, a exemplo dos serviços de inteligência existentes, a atividade de inteligência deveria ser entendida como um componente de luta entre adversários. Em segundo, pela possibilidade de utilização soberana, observados os princípios constitucionais, de meios humanos e técnicos para a coleta, análise e disseminação de informações relevantes para os processos de tomada de decisão na área de relações internacionais, política externa, defesa nacional e para o provimento da ordem pública. Esta coleta pode ser efetuada através de fontes ostensivas ou não." (ANTUNES, 2001, p. 168)
} 
Assim sendo, idealmente a atividade de inteligência cumpre papel informacional na área de segurança da sociedade e do Estado. Sua atuação é marcadas por duas dicotomias, descritas por Marco Cepik: (1) segurança estatal versus segurança individual e (2) segredo governamental versus direito à informação. Essas dicotomias não são uma característica exclusiva dos países periféricos, e também se fazem presentes nos países mais centrais e democráticos do mundo (CEPIK, 2005, p. 68).

A primeira dicotomia tem impacto direto no escopo de atuação da inteligência governamental, e, consequentemente, na definição de suas competências e limites. É dependente, além disso, do que um governo ou regime entende por ameaças e segurança.

A dicotomia segredo governamental versus direito à informação, ou sigilo versus transparência, relaciona-se ao princípio da publicidade que rege a Administração Pública. Segundo este, é imperativo que os atos da Administração Pública sejam expostos e abertos à inspeção social (MENDES et al., 2010, p. 969). É um princípio fundamental do Estado constitucional que o caráter público seja uma regra, e o segredo, a exceção (BOBBIO, 1997, p. 100).

Para garantir a efetividade dos serviços de inteligência, entretanto, é frequente a necessidade de sigilo. $\mathrm{Na}$ área da defesa e da segurança (entendidas, frise-se, dentro do conceito ocidental tradicional), há casos em que expor informações representaria um risco - se fossem divulgadas, por exemplo, as operações conduzidas para prever a atuação futura de organizações terroristas internacionais. Idealmente há que se procurar o equilíbrio entre publicidade e sigilo, maximizando a efetividade sem comprometer direitos humanos e civis ${ }^{3}$.

${ }^{3}$ A Lei 12.527 de 18 de novembro de 2011, em seu artigo 23, discrimina quais as informações passíveis de classificação por serem consideradas imprescindíveis à segurança da sociedade ou do Estado. 
Para tanto, a doutrina aponta duas importantes medidas que devem ser tomadas: a construção de uma estrutura legal adequada e o estabelecimento de mecanismos de controle eficazes. Uma questão importante dentro da estrutura legal é a definição do mandato das agências de inteligência, que será discutida brevemente no próximo tópico. O controle deve garantir que os serviços de inteligência prestem contas de seus atos à população através de seus representantes eleitos, e é assunto do próximo capítulo (BORN \& LEIGH, 2005, p. 13).

Mesmo em democracias antigas e plenamente consolidadas, manter a inteligência governamental sob controle não é uma tarefa simples. Em regimes transicionais ou pós-transicionais, em que a inteligência era utilizada como mecanismo de repressão política, há ainda o desafio de superar heranças não democráticas. Essa é a situação enfrentada pelo Brasil a partir dos anos 90, após a extinção do SNI.

Em geral, há pouca literatura sobre como as democracias em desenvolvimento lidam com a reforma da inteligência após a queda de regimes não democráticos. Para Thomas Bruneau e Florina Cristiana Matei, um país não pode ser considerado uma democracia plenamente consolidada até redirecionar seus aparatos de inteligência, de sistemas repressivos e sem controle para comunidades democráticas eficazes e transparentes. $\mathrm{O}$ autor e a autora consideram que essa modificação é dificultada por 4 fatores principais, dentre outros:

1. O estigma deixado pelos antecessores não democráticos das novas agências se mantém presentes por décadas, e gera desconfiança da população em relação à inteligência governamental como um todo. Ao longo de momentos transicionais, ela tende a apoiar a destruição dos aparatos de inteligência, e não sua reforma. 
2. Falta de profissionalismo, desde a captação de pessoal até programas de formação e atualização, passando pelo desenvolvimento e consolidação de códigos de ética específicos para cada agência. É frequente a manutenção do pessoal da agência predecessora, e há um decorrente risco de que estes agentes operem nos moldes do passado e passem suas "melhores práticas" adiante.

3. Governos de transição não tem experiência para realizar reformas de inteligência e os exemplos internacionais são em geral modelos pouco adequados. Além disso, costumam estar mais preocupados em realizar reformas políticas e econômicas. Como resultado, as mudanças na inteligência tendem a ser superficiais, com baixa alocação de recursos e má administração.

4. Em regimes onde a inteligência era um monopólio das forças armadas (Argentina, Brasil, Chile, Honduras e Espanha), a inteligência militar permanece dotada de grande autonomia (BRUNEAU \& CRISTIANA, 2010, pp. 761-762).

É possível encontrar os fatores apontados na transição democrática brasileira. O "estigma" a que se refere o autor trata-se da ideia de que há uma associação direta e necessária entre serviços de inteligência e violações de direitos humanos e civis. Esse raciocínio, por mais que esteja baseado em extensos registros históricos ou atuais, não leva a pressões ou debates capazes de gerar uma reforma da inteligência. Uma das promessas de campanha de Collor era a extinção do SNI, mas essa proposta não foi acompanhada de um projeto de reforma. Dada a impossibilidade de prescindir de um sistema de inteligência no mundo contemporâneo, a ausência de pressões e robustos projetos de reforma facilita a permanência de pessoal e formas de atuação antigas nas novas agências de inteligência. 
Além disso, um grande número de ex-funcionários do SNI foi integrado de forma pouco clara aos quadros da inteligência brasileira ao longo dos anos 90 (BRANDÃO, 2010, p. 141). Esses "herdeiros do SNI" permanecem poderosos e influentes até hoje, e protegidos de escrutínio externo (BRUNEAU \& CRISTIANA, 2010, p. 763).

Cabe ainda destacar que, em meio a um contexto de diversas reformas políticas e econômicas, pouca atenção foi dada pelo Executivo e, principalmente, pelo Legislativo ao tema da reforma da inteligência. Para Antônio Bittencourt Emílio,

"[A] atuação do Congresso em relação aos serviços secretos durante o período de elaboração da nova Constituição se deu de forma extremamente superficial e permitiu que a maioria das estruturas do SNI, eminentemente autoritárias, permanecessem quase intactas durante o processo de transição politica para a democracia." (EMÍLIO, 1992, p. 164)

Mesmo após a extinção do SNI em 1990 não houve envolvimento do Congresso na reformulação dos serviços de inteligência ${ }^{4}$. Esse envolvimento deu-se apenas mais tarde, no final dos anos 1990, e de forma muito limitada.

Outro fato que merece destaque é que, apesar da reestruturação dos órgãos de inteligência militar, seu escopo de atuação ainda inclui "inimigos internos": "não há mais a busca e apreensão de elementos considerados subversivos, mas a busca de informações e a vigilância de organismos de oposição legalmente instituidos ainda é patente" (BRANDÃO, 2010, p. 141). Conforme leciona Peter Gill, a inteligência militar formalmente é aquela associada à condução de táticas e estratégias de apoio a operações militares, mas agências militares costumam receber funções mais abrangentes em regimes caracterizados como "Estados de segurança nacional" (GILL \&

\footnotetext{
4 "Na Alemanha, após a queda do muro de Berlim, três comissões de representantes do governo e da sociedade trabalharam na liquidação da poderosa agência de inteligência Stasi. No Brasil, todavia, uma decisão imperial, sem maiores discussões no Congresso Nacional, selou o destino do SNI e abriu novo capítulo na história da inteligência civil brasileira."(ZAVERUCHA, 2008, p. 179)
} 
PHYTHIAN, 2012, p. 64). Foi este o caso do Brasil ao longo do regime militar.

Estes foram alguns dos grandes desafios para a inteligência brasileira após o final do regime militar. Ao longo dos anos 90, atuaram em conjunto com outros fatores para dificultar o redirecionamento democrático, a ainda hoje exercem influência sobre o sistema de inteligência do país.

\subsection{SISBIN e ABIN: A Reestruturação da Inteligência Brasileira nos Anos 90}

A Lei ${ }^{\circ}$ 9.883, de 7 de dezembro de 1999, criou o Sistema Brasileiro de Inteligência (SISBIN) e a Agência Brasileira de Inteligência (ABIN). O arcabouço institucional da nova agência foi encomendado por Fernando

Henrique Cardoso ao general Fernando Cardoso, ex-chefe do CIE. Consequentemente, embora a agência fosse civil, prevaleceu uma visão militarizada da inteligência em seu desenho institucional (ANTUNES, 2001, p. 146; ZAVERUCHA, 2008, p. 181)

Além de definir inteligência e contra inteligência, esta lei determina os fundamentos e responsabilidades do SISBIN e as competências da ABIN. Determina, ainda, que o controle e fiscalização externos da atividade de inteligência serão exercidos pelo Poder Legislativo, na forma a ser estabelecida em ato do Congresso Nacional.

Segundo o artigo $1^{\circ}, \S 1^{\circ}$, o SISBIN tem como fundamentos preservação da soberania nacional, a defesa do Estado Democrático de Direito e a dignidade da pessoa humana, devendo ainda cumprir e preservar os direitos e garantias individuais e demais dispositivos da Constituição Federal, os tratados, convenções, acordos e ajustes internacionais em que a República Federativa do Brasil seja parte ou signatário, e a legislação ordinária. Segundo a Exposição de Motivos do Projeto de Lei 3.651, que originou a referida lei, 
esse parágrafo tinha como objetivo limitar a atuação do SISBIN. O parágrafo único do artigo $3^{\circ}$, além disso, estabelece que as atividades de inteligência serão desenvolvidas "com irrestrita observância dos direitos e garantias individuais, fidelidade às instituições e aos princípios éticos que regem os interesses e a segurança do Estado". Na Exposição de Motivos, novamente foi afirmada a intenção de limitar a atuação da inteligência, tendo como base princípios constitucionais.

Essa vontade de estabelecer limites, contudo, esbarra em problemas criados pelo texto da própria lei. O artigo $1^{\circ}$ estipula que o SISBIN "integra as ações de planejamento e execução das atividades de inteligência do País, com a finalidade de fornecer subsídios ao Presidente da República nos assuntos de interesse nacional". Não define, contudo, o que seria "interesse nacional", de forma que o Poder Executivo fica livre para decidir o que a expressão compreende. A área de influência do novo sistema, além disso, é maior que a do SISNI, uma vez que inclui, no artigo $2^{\circ}$ todos os "órgãos e entidades da Administração Pública Federal que, direta ou indiretamente, possam produzir conhecimentos de interesse das atividades de inteligência" (ZAVERUCHA, 2008, p. 182).

A ABIN está posicionada no topo do sistema, ocupando no SISBIN posição similar à ocupada pelo SNI no SISNI. Inicialmente, a nova agência seria subordinada diretamente ao Presidente da República. Segundo Jorge Zaverucha, esse foi um dos argumentos usados por Fernando Henrique Cardoso para convencer o Congresso Nacional que a ABIN não se transformaria no SNI. Pouco depois da aprovação da Lei da ABIN, contudo, ele subordinou a ABIN ao Ministério do Gabinete de Segurança Institucional, chefiado pelo General Alberto Cardoso, oficial da ativa do Exército que exercia cargo de natureza militar (Medida Provisória $\mathrm{n}^{\circ}$ 1.999-17, de 11 de Abril de 2000, artigo $6^{\circ}$ ). Na prática, o chefe do GSI passava a decidir se e quando determinada investigação chegaria ao Presidente da República. O autor 
destaca, ainda, que os militares haviam optado por subordinar o SNI diretamente à presidência por considerarem frágil um arranjo em que havia intermediários, já que não restava garantida a chegada das informações ao Presidente. Fernando Henrique Cardoso abdicou, portanto, da prerrogativa de receber informações diretamente da ABIN (ZAVERUCHA, 2008, p. 184).

A competência da ABIN e da inteligência como um todo foi estabelecida de forma muito pouco precisa. Em primeiro lugar, a definição de inteligência no artigo $3^{\circ}$ não é acompanhada de uma definição do que seriam "fatos e situações de imediata ou potencial influência sobre o processo decisório governamental e sobre a salvaguarda e a segurança da sociedade e do Estado". As competências da ABIN também são estabelecidas de forma vaga, e não restringem a ampla definição dada às atividades de inteligência ${ }^{5}$.

Com a criação do Subsistema de Inteligência de Segurança Pública no âmbito do SISBIN em 2000, a ABIN tornou-se, ainda, órgão central da inteligência de segurança pública. Passa a participar, assim, da segurança das cidades, além de outros temas relacionados à segurança pública (ANTUNES, 2001, p. 187).

Interessante destacar que o padrão ocidental típico foi apresentado como modelo para nosso sistema. Em especial, foi destacada pelo General Alberto Cardoso a adaptação do modelo canadense para a construção da ABIN (ANTUNES, 2001, p. 169).

A "adaptação", contudo, parece ter deixado de considerar aspectos essenciais da legislação criadora da agência canadense, a Canadian Security Intelligence Service - CSIS. O Canadian Security Intelligence Act, de 1985, incumbe o CSIS de

\footnotetext{
5 “Art. $3^{\circ}$ Fica criada a Agência Brasileira de Inteligência- ABIN, órgão de assessoramento direto ao Presidente da República, que na posição de órgão Central do Sistema Brasileiro de Inteligência, terá a seu cargo planejar, executar, coordenar, supervisionar e controlar as atividades de inteligência do País, obedecidas a politica a as diretrizes superiormente traçadas nos termos desta Lei." Lei 9.883 de 7 de dezembro de 1999.
} 
"coletar, por investigação ou outros meios, na extensão em que for estritamente necessário, analisar e reter informações e inteligência referentes a atividades que levantem suspeitas, em bases razoáveis, de constituir ameaças à segurança do Canadá e, em relação a elas, se reportar e aconselhar o governo do Canadá" "6.

\section{Entretanto, em seção intitulada "Definições", a lei traz uma explicação esmiuçada do que está incluído na expressão “ameaças à segurança do Canadá":}

“ 'Ameaças à segurança do Canadá' significa: ${ }^{7}$

a) espionagem ou sabotagem que seja contra o Canadá ou seja prejudicial aos interesses do Canadá, ou atividades direcionadas para, ou em apoio de, tal espionagem ou sabotagem,

b) atividades influenciadas pelo exterior, dentro ou em relação ao Canadá, que sejam prejudiciais aos interesses do Canadá e que sejam clandestinas ou enganadoras ou envolvam uma ameaça a qualquer pessoa,

c) atividades dentro ou em relação ao Canadá direcionadas para, ou em apoio de, ameaça ou uso de atos de séria violência contra pessoas ou propriedades com o propósito de atingir um objetivo político, religioso ou ideológico dentro do Canadá ou em outro Estado, e

d) atividades direcionadas a minar por atos ilegais encobertos, ou direcionadas para ou destinadas a, em última análise, levar à destruição ou derrubada por meio de violência do sistema de governo estabelecido constitucionalmente no Canadá,

6 "12. The Service shall collect, by investigation or otherwise, to the extent that it is strictly necessary, and analyse and retain information and intelligence respecting activities that may on reasonable grounds be suspected of constituting threats to the security of Canada and, in relation thereto, shall report to and advise the Government of Canada." Canadian Security Intelligence Act, 1985.

7 ". 'threats to the security of Canada' means

(a) espionage or sabotage that is against Canada or is detrimental to the interests of Canada or activities directed toward or in support of such espionage or sabotage,

(b) foreign influenced activities within or relating to Canada that are detrimental to the interests of Canada and are clandestine or deceptive or involve a threat to any person,

(c) activities within or relating to Canada directed toward or in support of the threat or use of acts of serious violence against persons or property for the purpose of achieving a political, religious or ideological objective within Canada or a foreign state, and

(d) activities directed toward undermining by covert unlawful acts, or directed toward or intended ultimately to lead to the destruction or overthrow by violence of, the constitutionally established system of government in Canada,

but does not include lawful advocacy, protest or dissent, unless carried on in conjunction with any of the activities referred to in paragraphs (a) to (d)." 
mas não inclui a defesa de opiniões, os protestos ou as dissidências legais, a não ser que conduzidos em conjunto com qualquer das atividades a que se referem os parágrafos (a) a (d)."

Fica claro, portanto, que a atuação da CSIS é bem mais limitada que a da $\mathrm{ABIN}$, e se restringe a sabotagem e espionagem, violência e terrorismo político e subversão, sendo esta última cuidadosamente diferenciada do dissenso legítimo (ANTUNES, 2001, p. 169). Conforme esclarece Priscila Antunes, "o serviço de inteligência que se propõe a 'dar informações para governar' é algo intrinsecamente diferente das competências das atividades de inteligência observadas nos outros países" (ANTUNES, 2001, p. 154).

A Lei $n^{0}$ 9.883, além disso, não faz distinção entre inteligência civil e inteligência militar. Assim, ficou aberta a brecha para a entrada de militares em um sistema que deveria ser eminentemente civil (ZAVERUCHA, 2008, p. 182). A inteligência militar, conforme mencionado no tópico anterior, continua dotada de grande liberdade de atuação e conta com mecanismos de vigilância sobre a oposição legalmente constituída. Esse problema se insere num contexto maior e mais problemático, relativo às relações civil-militares no Brasil e em outros países da América Latina:

"[N]em mesmo os analistas mais otimistas em relação aos casos do Brasil, ou mesmo da Argentina e do Uruguai, chegam a afirmar que estes paises hoje possuem sistemas de controle democrático plenamente institucionalizados sobre as Forças Armadas. A razão principal para esta relutância, especialmente no caso brasileiro, é a extrema fragilidade institucional do novo Ministério da Defesa vis-à-vis os comandos das três forças, bem como a falta de assertividade das comissões parlamentares permanentes e do Congresso brasileiro como um todo no exercício de suas capacidades de supervisão e influência sobre prioridades, tanto políticas quanto orçamentárias.” (CEPIK, 2005, p. 76)

Por todo o exposto acima, fica claro que a Lei $\mathrm{n}^{\circ} 9.883$ é repleta de indefinições patentes que representam um obstáculo para a democratização da inteligência brasileira. Soma-se a isso a inexistência de uma Política Nacional 
de Inteligência capaz de pautar minimamente suas prioridades, e o resultado é um sistema confuso e sujeito a diversas interpretações.

Conforme leciona Marco Cepik, a indefinição de prioridades e ênfases temáticas gera ainda outro problema, que é a "alocação de recursos escassos para o cumprimento de uma missão definida de maneira genérica e volúvel segundo a crise política do momento" (CEPIK, 2005, p. 91). Em suma, além de ser propícia a grandes e frequentes abusos, a legislação brasileira compromete a eficácia e a eficiência da própria inteligência, reduzindo a alocação de recursos para áreas nas quais ela de fato deveria agir.

Esse grau de indefinição é expressamente desaconselhado no guia de melhores práticas para o controle da inteligência "Making Intelligence Accountable: Legal Standards and Best Practices". Desenvolvido pelo Centro de pelo Controle Democrático das Forças Armadas, em Genebra, pelo Parlamento Norueguês e pelo Centro de Direitos Humanos da Universidade de Durham, essa publicação compreende extensa análise de sistemas de inteligência do mundo inteiro, e a partir das variadas experiências elabora um guia de melhores práticas. Este, por sua vez, esclarece que um fator chave para a accountability das agências de inteligência é que seu papel e esfera de operação devem estar claramente definidos, e que é claramente melhor especificar por meio de legislação detalhada os vários aspectos da segurança nacional do que deixar o mandato das agências de inteligência externas e internas essencialmente aberto através do uso de frases como "proteção da segurança do Estado" (Born \& Leigh, 2005, p. 29).

Nesse ponto, são recomendadas as seguintes melhores práticas:

1. O papel de uma agência de inteligência interna ou externa deve ser claramente definido e limitado a assuntos que devem ser especificados em detalhes e envolver sérias ameaças à segurança nacional e ao tecido da sociedade civil. 
2. Os conceitos de ameaça à segurança nacional e ao tecido da sociedade civil devem estar especificados legalmente.

3. A competência territorial de uma agência de inteligência externa ou externa deve ser claramente definida e quaisquer poderes para agir fora deste território devem ser acompanhados de salvaguardas.

4. As tarefas e poderes da agência dentro de seu mandato devem ser claramente definidas em legislação, promulgada pelo parlamento.

5. Especialmente em Estados pós autoritários, é importante ter salvaguardas legais e institucionais, prevenindo o mau uso das agências de inteligência contra a oposição política doméstica.

A partir do exposto acima, nota-se que a legislação brasileira não cumpre integralmente nenhuma das práticas sugeridas. Essa situação está relacionada à influência dos quadros e práticas da inteligência do regime militar, mas também se deve ao grande desinteresse do Executivo e do Legislativo em produzir mudanças reais ${ }^{8}$.

Esse potencial para uma atuação extremamente ampla foi confirmado na prática. Em 2002, o General Alberto Cardoso declarou serem as principais áreas em que a inteligência brasileira havia produzido conhecimentos com significativo impacto nas decisões governamentais: o acompanhamento de movimentos separatistas, o acompanhamento do atendimento das reivindicações dos movimentos sociais, as questões fundiárias, a proteção da população indígena, meio ambiente e biodiversidade, oportunidades e óbices para o desenvolvimento nacional (particularmente nas áreas de tecnologia de ponta e de aproveitamento de recursos naturais), grilagem de terras

\footnotetext{
8 " $\mathrm{O}$ contexto mais geral das dificuldades de institucionalização das novas estruturas de inteligência no Brasil é dado pela falta de disposição das elites políticas no Poder Executivo e no Congresso Nacional em lidar com o problema da efetividade e eficiência dos serviços e unidades especializados no cumprimento de missões e mandatos legais definidos muito genericamente (o que remete às questões essenciais de prioridades, divisão de trabalho entre as agências, especialização, recursos, liderança etc.). " (CEPIK, 2005, p. 92)
} 
(especialmente na região amazônica), proliferação de armas de destruição em massa (em apoio às delegações brasileiras e agências multilaterais), segurança pública nos estados federados (em cooperação com o SISP) combate ao crime transnacional organizado, narcotráfico, tráfico de armas e "lavagem" de dinheiro, prevenção do terrorismo, movimentação de integrantes de organizações terroristas internacionais, acompanhamento e avaliação de conflitos externos (e potenciais reflexos para o país), acompanhamento das ações resultantes da aplicação do Plano Colômbia e dos seus possíveis desdobramentos para o Brasil (CEPIK, 2005, pp. 91-92).

Cabe, aqui, fazer observação quanto à Política Nacional de Inteligência

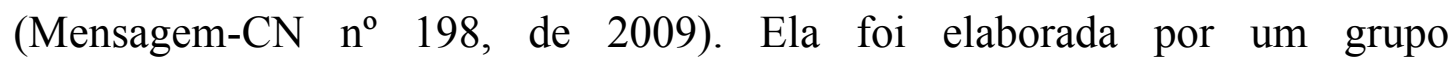
interministerial coordenado pelo GSI, e enviada para a CCAI em meio de 2000. A comissão aprovou o projeto no final de 2001, e apresentou propostas de alteração (BRANDÃO, 2010, p. 155). A PNI foi devolvida, então, ao GSI, mas até o momento o Executivo ainda não editou um decreto sobre o tema. A PNI apresentada à CCAI divide-se em 8 partes: (1) introdução, (2) pressupostos da atividade de inteligência, (3) o Estado, a sociedade e a inteligência, (4) os ambientes nacional e internacional, (5) instrumentos, (6) principais ameaças, (7) objetivos da inteligência nacional e (8) diretrizes para a atividade de inteligência. Alguns destes tópicos guardam conexão direta com a questão do escopo de atuação das atividades de inteligência.

Ao tratar dos ambientes nacional e internacional, o documento reitera o entendimento de que as condições atuais da política global não permitiriam clara separação entre questões internas e externas na área da inteligência. $O$ parecer da CCAI considerou a explicação dada nesse item demasiado 
simplista, e cobrou maior atenção a esse aspecto do texto, mas sem tecer críticas específicas ao conteúdo 9 .

As principais ameaças listadas pela PNI são 11: (1) espionagem, (2) sabotagem, (3) interferência externa, (4) ações contrárias à soberania nacional, (5) ataques cibernéticos, (6) terrorismo, (7) atividades ilegais envolvendo bens de uso dual e tecnologias sensíveis, (8) armas de destruição em massa, (9) criminalidade organizada, (10) corrupção e (11) ações contrárias ao Estado Democrático de Direito. Aqui, a CCAI destacou que não havia definição do que seriam "ameaças", e recomendou que seria interessante incluir o que se entende pelo termo, com comentários sobre quem ou o quê está sendo ameaçado. Concordou que os itens listados eram ameaças ao Estado, à sociedade e/ou às instituições democráticas, mas destacou não ser possível extrair do texto da PNI quais os critérios utilizados para chegar a esse rol de ameaças, e o motivo de sua ordem de apresentação.

As diretrizes estabelecidas pela PNI são: (1) prevenir ações de espionagem no país, (2) ampliar a capacidade de detectar, acompanhar e informar sobre ações adversas aos interesses do Estado brasileiro no exterior, (3) prevenir ações de sabotagem, (4) expandir a capacidade operacional da inteligência no espaço cibernético, (5) compartilhar dados e conhecimentos, (6) ampliar a confiabilidade do SISBIN, (7) expandir a capacidade operacional da inteligência, (8) fortalecer a cultura de proteção de conhecimentos, (9) cooperar na proteção das infraestruturas críticas nacionais e (10) cooperar na identificação de oportunidades ou áreas de interesse para o Estado brasileiro.

Apesar da falta de clareza em relação aos conceitos utilizados (BRANDÃO, 2010, p. 155), cada uma das ameaças e diretrizes listadas é acompanhada de alguma explicação e delimitação de significado, e auxiliam no estabelecimento de prioridades na atividade de inteligência. A PNI

\footnotetext{
${ }^{9}$ O parecer pode ser acessado no site do Senado, no endereço:

$<\mathrm{http} / /$ www.senado.gov.br/atividade/materia/getPDF.asp?t=82768\&tp=1>, acesso em 13 de setembro de 2014 .
} 
representaria ao menos algum norte para a comunidade de inteligência, que vêm atuando sem objetivos e limites, o que aumenta o risco de abusos e irregularidades (GONÇALVES, 2013, p. 214). 


\section{O Controle Parlamentar das Atividades de Inteligência no Brasil}

\subsection{Observações iniciais sobre controle}

O controle da Administração Pública é de importância crucial no Estado de Direito, para impedir que ela se "desgarre de seus objetivos, que desatenda as balizas legais e ofenda interesses públicos ou dos particulares" (BANDEIRA DE MELLO, 2009, p. 935). Este controle pode ser interno ou externo. O controle interno é efetuado pela própria Administração Pública, ou seja, pelo

Poder Executivo. O controle externo é exercido por órgãos alheios à Administração, e compreende o controle parlamentar direto, o controle exercido pelo Tribunal de Contas e o controle jurisdicional (BANDEIRA DE MELLO, 2009, pp. 937, 940).

Uma vez que este capítulo faz referências à doutrina anglo-saxônica, há que se esclarecer ainda a distinção que ela estabelece entre control e oversight. Control se refere à administração ou direção de uma agência, que é geralmente obtida por regulação administrativa ou ordens; oversight é a supervisão de uma agência, incluindo suas atividades em andamento (GILL, 2002). A palavra controle será utilizada no sentido que tem em português, ou seja, "a faculdade de vigilância, orientação e correção que um Poder, órgão ou autoridade exerce sobre a conduta funcional de outro" (MEIRELLES et al., 2010, p. 697). Quando for feita referência a control e oversight, no sentido utilizado pela doutrina anglo-saxônica, serão utilizados os termos "direção" e "supervisão", respectivamente. 


\subsection{Por que controlar as atividades de inteligência?}

Ao longo dos últimos trinta anos, o controle da inteligência foi tema frequente na política de diversos países. Naqueles de tradição democrática mais antiga, a discussão foi impulsionada por escândalos envolvendo abusos e violações de direitos por parte das agências de inteligência; em outros locais, acompanhou a transição entre regimes autoritários e democracia (GILL, 2002).

$\mathrm{O}$ objetivo do controle da inteligência deve ser duplo, envolvendo tanto a eficácia quanto a legitimidade (GILL, 2002). A legitimidade exige observância das normas constitucionais, legais e regulamentares vigentes. A eficácia, por sua vez, pressupõe uma relação adequada entre os recursos públicos empregados e o produto obtido (UGARTE, 2002).

Embora toda atividade governamental deva estar sujeita a controle, a busca por mecanismos capazes de realizá-lo de forma eficaz é particularmente importante no caso da inteligência. A publicação "Making Intelligence Accountable: Legal Standards and Best Practices" estabelece cinco motivos pelos quais o controle público da inteligência é de extrema importância (BORN \& LEIGH, 2005, pp. 16-17).

Em primeiro lugar, o segredo característico das atividades de inteligência pode escondê-las do olhar público, de forma que é crucial que o Legislativo e o Executivo possam acompanhar de perto sua atuação. Esse fator é também o maior desafio do controle da inteligência. $O$ acesso dos órgãos de controle à informação define, na prática, se a sua atuação será eficaz ou meramente figurativa (GILL \& PHYTHIAN, 2012, p. 182).

Em segundo lugar, agências de inteligência possuem poderes especiais que podem limitar direitos humanos, como a permissão para acessar comunicações privadas. No Brasil, a ABIN não tem permissão legal para realizar interceptações telefônicas, sendo esta exclusiva das autoridades policiais (art. 50, XII, da Constituição Federal). Ainda assim, tem acesso 
privilegiado às informações produzidas por todo o sistema de inteligência brasileiro.

Em terceiro, após o término da Guerra Fria e, especialmente, após 11 de setembro de 2001, quase todas as comunidades de inteligência passaram por um processo de ajuste às ameaças transnacionais. Era importante que esse processo fosse supervisionado por autoridades civis eleitas. Além disso, serviços de inteligência geralmente são resistentes a mudanças e dotados de certa inércia burocrática, e interferência externa pode ser necessária para garantir a implementação de novas ideias. Aqui, é importante ressaltar que a publicação foi escrita em 2005, e o 11 de setembro era um fato recente. Ainda hoje, contudo, as agências de inteligência passam por um reajuste de suas condutas para lidar com ameaças transnacionais. A inteligência brasileira também deve ser capaz de responder a elas, mas seu caso é diferente do descrito neste tópico. Isso porque ele se refere aos países que, como os Estados Unidos e a Inglaterra, tinham seus aparatos de inteligência equipados para reagir a ameaças provocadas por Estados estrangeiros. Após o fim da Guerra Fria, as ameaças transnacionais ganharam importância. $\mathrm{O}$ atentado de 11 de setembro de 2001 pode ser considerado uma falha de inteligência, resultante da dificuldade da atividade em se adaptar às novas necessidades.

Em quarto lugar, serviços de inteligência tem como tarefa a coleta e análise de informações sobre possíveis ameaças. Realiza, ainda, uma avaliação de ameaças que é ponto de partida para outras forças de segurança do Estado. É importante que essa avaliação seja realizada sob direção democrática, já que ela pressupõe uma priorização de ameaças dotada de implicações políticas. $\mathrm{Na}$ legislação brasileira, o artigo $4^{\circ}$, III, diz ser competência da ABIN “avaliar as ameaças, internas e externas, à ordem constitucional".

O quinto motivo citado se aplica a países que viveram governos autoritários e fizeram transição recente para a democracia. Reformar agências de inteligência que atuaram como ferramentas de repressão exige um 
monitoramento cuidadoso pelo Executivo e pelo Legislativo, e é este o cenário enfrentado pelo Brasil. Sem mecanismos de controle eficazes, dificilmente a inteligência brasileira será plenamente adaptada a um ambiente democrático.

\subsection{Conteúdo do controle da inteligência}

Para José Manuel Ugarte, o controle da inteligência supõe, em primeiro lugar, a verificação da legitimidade das atividades desenvolvidas. Esse controle pode ser iniciado de ofício ou por requerimento de órgão governamental, ou por denúncias de particulares. O controle deve avaliar também o cumprimento por parte dos órgãos de inteligência das normas que definem suas competências. Nesse caso, há preocupação tanto com possíveis abusos quanto com a busca por eficiência. Cabe observar aqui que, para tanto, uma clara definição de competências seria extremamente importante.

$\mathrm{O}$ autor argumenta que qualquer aspecto que possa interferir na qualidade do produto, na capacidade dos diretores, a oportunidade em que o produto chega aos consumidores e na adequada relação entre produtores e consumidores poderia também ser objeto de controle. Deve-se, ainda, avaliar a eficiência do gasto através do exame dos resultados e produtos obtidos (UGARTE, 2002).

Peter Gill, por sua vez, defende que os parâmetros de controle não devem incluir apenas legalidade, mas devem também considerar questões éticas e de direitos humanos. (GILL \& PHYTHIAN, 2012, p. 170).

É certo, de qualquer forma, que a capacidade de controle dos órgãos dele encarregados deve incluir todas as atividades da inteligência, em todas as suas etapas, e verificar se sua atuação se adequa à legislação em vigor. Deve, ainda, objetivar maximizar a eficiência, garantindo que os recursos sejam empregados de forma adequada. 


\subsection{Formas de controle da Inteligência}

Em seu glossário, "Making Intelligence Accountable" traz a seguinte definição para "Accountability democrática dos serviços de inteligência":

"Ainda que o segredo seja uma condição necessária do trabalho dos serviços de inteligência, a inteligência em um Estado democrático liberal deve trabalhar no contexto da legalidade, mecanismos de controle e linhas transparentes de responsabilidade. A accountability democrática dos serviços de inteligência portanto identifica a correção e determina a eficácia dos serviços de inteligência sob estes parâmetros. Isso envolve cinco pilares distintos mas interdependentes: (1) controle executivo; (2) supervisão parlamentar; (3) revisão judicial; (4) supervisão independente em prol do público geral; $e$ (5) controle interno pelos serviços de inteligência ${ }^{10}$." (BORN; LEIGH, 2005, p. 138)

$\mathrm{O}$ arranjo exato adotado em cada país varia de acordo com sua história e cultura política (GILL \& PHYTHIAN, 2012, p. 171). Em geral, envolve uma série de atores e instituições agindo de forma integrada ou complementar. Dos exemplos citados acima, são internos os controles executivo e agencial, enquanto os demais são externos.

Cada um deles é dotado de funções típicas diferente. O controle interno agencial é realizado por um setor da agência capaz de avaliar a conduta de seus servidores e suas atividades. Este setor deve estar diretamente ligado ao Diretor-Geral, prestando contas somente a ele. $\mathrm{O}$ controle interno pelo Executivo pode ser feito através de supervisão ministerial, comissões de segurança e por um inspetor geral (GONÇALVES, 2010, pp. 80, 81). Além de supervisionar, o Executivo controla através da direção, definindo tarefas, prioridades e transferindo recursos (BORN \& LEIGH, 2005, pp. 13).

\footnotetext{
10 "Democratic Accountability of Intelligence Services

Although secrecy is a necessary condition of intelligence services' work, intelligence in a liberal democratic state needs to work within the context of the rule of law, checks and balances, and transparent lines of responsibility. Democratic accountability of intelligence services thus identifies the propriety and determines the efficacy of intelligence services under these parameters. This involves five distinct yet interdependent pillars: (1) executive control; (2) parliamentary oversight; (3) judicial review; (4) independent oversight on behalf of the general public; and (5) internal control by the intelligence services."
} 
O controle externo deve ser exercido de forma eficaz, mas deve respeitar as prerrogativas de cada um dos Poderes. No controle externo pelo judiciário, este exerce sua função de proteger a sociedade contra abusos de poder e violações de direitos. O controle externo pelo Legislativo, por sua vez, geralmente envolve a supervisão de atividades e gastos.

O controle popular pode ser exercido por organizações não governamentais, monitorando a ocorrência de abusos ou violência; pela mídia, quando ela expõe crises ou escândalos; e pela população, que pode apresentar denúncias e reivindicar a adoção de novas politicas, dentre outras formas possíveis.

\subsection{O Controle da Inteligência no Brasil}

No ordenamento jurídico brasileiro, o controle é um poder-dever dos órgãos a que a lei atribui essa função. Não pode ser renunciado ou retardado, sob pena de responsabilidade de quem se omitiu. Abrange a fiscalização e a correção dos atos ilegais e, em certa medida, dos inconvenientes e inoportunos (DI PIETRO, 2011, p. 736).

O controle interno da inteligência brasileira ocorre através de mecanismos de controle agenciais e da atuação de Ministros do Executivo. Já o controle externo é efetuado pelo Poder Judiciário, pelo Ministério Público, e pelo Poder Legislativo, além da atuação de grupos que se situam fora da estrutura estatal.

O controle interno agencial na ABIN é realizado por seu Diretor-Geral e por uma Corregedoria-Geral. Até 2008, o Diretor-Geral era o único responsável pelo controle agencial, mas o Decreto $n^{\circ} 6.408$ criou a nova Corregedoria-Geral. Ainda assim,

"[O] controle das atividades da ABIN estrutura-se, basicamente, na supervisão do Diretor-Geral do órgão, e nas orientações dele emanadas. O princípio da hierarquia ainda carrega significativa importância em virtude da cultura militar que permanece 
em alguns setores da agência, senão em sua própria memória organizacional. Daí a importância da figura do Diretor-Geral, que administra o dia a dia do órgão e orienta as atividades de caráter operacional." (GONÇALVES, 2010, p. 154)

As incumbências do Diretor-Geral são definidas no art. 18 do Decreto ${ }^{\circ}$ 6.408, de 24 de março de 2008. Elas incluem "planejar, dirigir, orientar, supervisionar, avaliar e controlar a execução dos projetos e atividades da ABIN"; "elaborar e editar o regimento interno da ABIN"; "decidir sobre os processos administrativos disciplinares, quando a pena for de suspensão até trinta dias"; e "aprovar planos de operações de inteligência, contrainteligência e contraterrorismo", dentre outras. É possível verificar, portanto, que lhe cabem atos tanto de direção quanto de supervisão.

De acordo com o art. 11, parágrafo único, da Lei $\mathrm{n}^{\circ}$ 9.883, a escolha e nomeação do Diretor-Geral da ABIN são privativas do Presidente da República, e devem ser aprovadas pelo Senado.

A Corregedoria-Geral foi criada em 2008, e suas competências estão descritas no art. $7^{\circ}$ do Decreto $\mathrm{n}^{\circ}$ 6.408. Tem função disciplinar relativa à conduta dos servidores da $\mathrm{ABIN}$, e não avalia o desempenho ou a regularidade das operações. No âmbito do controle agencial, cabe ainda destacar que o Departamento de Administração e Logística e a Secretaria de Planejamento, Orçamento e Administração também realizam funções de controle, mas estas têm caráter financeiro e administrativo, e não operacional (GONÇALVES, 2010, p. 157-159). Esses três órgãos realizam funções de supervisão.

Já o controle exercido pelo executivo se apoia em três pontos: o Ministro-Chefe do GSI, a Câmara de Relações Exteriores e Defesa Nacional do Conselho de Governo (CREDEN) e o sistema que tem à frente a Controladoria Geral da União.

O Ministro-Chefe do GSI é "de fato e de direito o chefe do serviço de inteligência" e dele "emanam as diretrizes e orientações para o serviço secreto brasileiro" (GONÇALVES, 2010, p. 161). Exerce funções de direção e 
supervisão. Conforme mencionado anteriormente, a princípio a ABIN ficaria subordinada diretamente à Presidência da República. Sua subordinação ao GSI faz com que uma agência civil responda a órgão militar, uma vez que o gabinete é a antiga Casa Militar, e seu Chefe é sempre militar da ativa. Interessante destacar que o protagonismo do GSI acaba por relegar o DiretorChefe da ABIN a um papel coadjuvante. Apenas este último, contudo, tem sua indicação aprovada pelo Legislativo, que não tem nenhum papel na escolha do Ministro-Chefe do GSI.

Para Joanisval Gonçalves, em países saídos de regimes autoritários, é comum que os políticos não queiram se envolver com as atividades de inteligência. A subordinação da ABIN ao GSI teria sido uma solução para evitar esse envolvimento (GONÇALVES, 2010, p. 79). Essa organização, contudo, favorece a permanência de valores militares na estrutura da ABIN e, de forma geral, a militarização da inteligência brasileira.

Em 2011, foi noticiado pela imprensa que Dilma Roussef pretendia desvincular a ABIN do GSI. A medida teria sido uma resposta a reivindicações de servidores civis da ABIN, insatisfeitos com a militarização da agência. Esses funcionários teriam enviado carta à Presidência da República em que pediam o fim da subordinação ao GSI, uma vez que não queriam continuar a ser a "Tropa do Elito" (DE CARVALHO, 2011; MONTEIRO, 2011). A expressão é referência ao atual Ministro-Chefe do GSI, o General José Elito. À época, contudo, a estrutura da inteligência brasileira não foi alterada.

O Ministro-Chefe do GSI é, ainda, presidente da CREDEN. Esta câmara deveria supervisionar e executar a Política Nacional de Inteligência. Como esta não existe até hoje, a ABIN trabalha com diretrizes da CREDEN. No controle interno, cabe citar ainda a atuação da CGU, que não exerce fiscalização de enfoque finalístico, mas verifica a legalidade e os resultados quanto à eficácia, eficiência, gestão orçamentária, financeira e patrimonial (GONÇALVES, 2010, p. 164-165). 
$\mathrm{Na}$ esfera do controle externo, aquele exercido pelo Judiciário dá-se no caso concreto e, portanto, necessariamente a posteriori. O Ministério Público exerce função fiscalizadora, conforme explicitado no texto constitucional: "[O Ministério Público deve] zelar pelo efetivo respeito dos Poderes Públicos e dos serviços de relevância pública aos direitos assegurados nesta Constituição" (art. 129, II, da Constituição Federal).

O controle parlamentar é provavelmente a forma mais importante de controle externo, embora o Legislativo brasileiro tenha pouca tradição de envolvimento com as atividades de inteligência. Esse assunto será abordado no próximo capítulo.

Quanto ao controle popular, há poucos exemplos de envolvimento da sociedade civil na atividade da inteligência brasileira desde a extinção do SNI. Nas ocasiões em que a ABIN envolveu-se em escândalos, como a Operação Satiagraha em 2008, a mídia participou em grande escala de sua divulgação e cobertura, mas de forma geral dá pouca atenção aos problemas existentes na inteligência brasileira. $\mathrm{O}$ estudo da inteligência no meio acadêmico brasileira também é bastante limitado, salvo raras exceções.

As observações feitas acima sobre controle da inteligência se referem principalmente à $\mathrm{ABIN}$. Isso porque há pouca informação disponível sobre os outros componentes da inteligência brasileira, e em especial sobre a inteligência militar.

Conforme esclarece o ex-analista de informações da ABIN e consultor legislativo do Senado Joanisval Gonçalves, há poucas críticas a tecer quanto ao controle da inteligência brasileira devido a um simples fato: ele praticamente inexiste. Sua execução, além disso, é extremamente dificultada pela vagueza e várias indefinições presentes na legislação brasileira para a inteligência. Mais uma vez, fica clara a pouca adequação da inteligência brasileira a um regime democrático. 


\subsection{Controle e o Poder Legislativo}

O Parlamento exerce funções decorrentes do princípio da soberania popular, em papel que lhe atribui o direito e o dever de intervir em todas as etapas do processo político. Suas atividades podem ser classificadas em quatro funções fundamentais: representação, legislação, controle do Executivo e legitimação (BOBBIO et al., 1998, p. 883).

O controle do Executivo é, portanto, uma das funções primordiais do Legislativo. São várias as formas de exercê-la, mas em geral sua forma mais comum é o poder de expor à opinião pública a atuação do Executivo. Em geral, exige a existência de um público atento aos acontecimentos políticos, e capaz de influir em seu processo (BOBBIO et al., 1998, p. 885).

Na Constituição Federal brasileira, entre as competências exclusivas da Câmara e do Senado, listadas respectivamente nos artigos 49 e 52, está a fiscalização a priori ou a posteriori dos atos do Executivo. $\mathrm{O}$ art. 70 diz, ainda, que a fiscalização contábil, financeira, orçamentária, operacional e patrimonial da União e das entidades da administração direta e indireta, quanto à legalidade, legitimidade, economicidade, aplicação das subvenções e renúncia de receitas, será exercida pelo Congresso Nacional, mediante controle externo.

O controle do Legislativo sobre o Executivo inclui:

1. Sustação de atos e contratos do Executivo;

2. Convocação de Ministros e requerimentos de informações; recebimento de petições, queixas e representações;

3. Comissões Parlamentares de Inquérito;

4. Autorizações ou aprovações do Congresso necessárias para atos concretos do Executivo;

5. Poderes controladores privativos do Senado;

6. Julgamento das contas do Executivo; 
7. Suspensão e destituição ( "impeachment") do Presidente ou de Ministros (BANDEIRA DE MELLO, 2009, 940-943).

O Tribunal de Contas, além disso, atua como auxiliar do Legislativo em matérias orçamentárias: "o controle externo, a cargo do Congresso Nacional, será exercido com o auxílio do Tribunal de Contas da União" (art. 71, Constituição Federal).

\subsection{O Controle das atividades de inteligência pelo Poder Legislativo}

A doutrina relativa ao controle da inteligência pelo Legislativo começou a se desenvolver em maior escala durante a Guerra Fria. Até os anos 1970, qualquer tentativa de estabelecer estruturas de controle para as agências de inteligência seria considerada ingênua e perigosa. Desde então, uma série de escândalos envolvendo abusos por parte de agentes de inteligência resultou na busca por elaborar sistemas de controle capazes de proteger as liberdades civis (GILL \& PHYTHIAN, 2012, p. 171).

A atuação do Legislativo, nesse momento, foi fundamental para a estruturação dos mecanismos de controle. Nos Estados Unidos, os serviços de inteligência tinham alto grau de autonomia até meados dos anos 1970, e sua supervisão por comissões congressuais se limitava ao controle orçamentário. Após escândalos como a tentativa de invasão à Baía dos Porcos e o caso Watergate, o Congresso americano acusou o Executivo de falhar ao não medir as consequências políticas de ações de inteligência. Ademais, foram identificadas violações a direitos civis dos cidadãos do país pelo $\mathrm{FBI}$, que chegou a perseguir e chantagear figuras políticas importantes como Martin Luther King Jr. (GONÇALVES, 2010, p. 98). 
Os envolvidos se recusaram a responder às questões levantadas pelo Congresso, e a dificuldade de atribuir responsabilidades levou a um movimento entre os parlamentares no sentido de desenvolver mecanismos mais rígidos de controle da inteligência. Comitês passaram a cobrar relatórios das atividades desenvolvidas e a exigir dados sobre operações antes que elas fossem realizadas. As mudanças enfrentaram grande resistência do Poder Executivo, mas acabaram por ser implementadas (ANTUNES, 2001, p. 114).

Após a experiência americana e ocorrências similares em outros países, o controle legislativo passa a ser visto internacionalmente como a principal forma de controle das atividades de inteligência, e condição necessária para sua real adequação um regime democrático. Segundo Priscila Carlos Brandão,

\begin{abstract}
"A participação do Poder Legislativo na elaboração e no controle da atividade de inteligência é um aspecto crucial para a aprovação e para a legitimação dos investimentos que são feitos na área de inteligência. A supervisão congressual precisa se ater a duas questões básicas: o controle da atuação das agências, que têm como condição de eficácia o segredo e a clandestinidade, e o controle orçamentário, pois trata-se de uma atividade altamente especializada, com pesados requisitos tecnológicos que recolocam na agenda a tensão entre tecnocracia e governo representativo." (ANTUNES, 2001, p. 112)
\end{abstract}

A autora destaca o papel do legislativo na aprovação e legitimação das atividades de inteligência. Isso se dá devido a características inerentes ao próprio Poder Legislativo. Nas palavras de Norberto Bobbio,

"Os Parlamentos, na verdade, não só transmitem demandas e pedidos, como também, em geral, manifestações de consenso e dissenso, de apoio político ou de contestação, em face das estruturas de Governo. [...] Intermediário do apoio ou dissenso, o Parlamento ajuda a conferir ou a subtrair legitimidade política ao Governo." (BOBBIO et al., 1998, p. 884).

O controle parlamentar da inteligência, assim, confere legitimidade à atividade, e pode ser entendido como um compromisso entre dois interesses conflitantes: a necessidade de segredo e o desejo de trazer a opinião pública 
para dentro das agências de inteligência (SCHULSKY \& SMITH, 2002, p. 145).

\subsection{Os desafios do controle parlamentar da inteligência}

A estruturação de um mecanismo de controle parlamentar levanta uma série de perguntas. Qual será o seu mandato, ou sobre o que exercerão supervisão? Como serão escolhidos e por quem? Devem passar por um processo de aprovação? Que poderes terão para obter acesso ao pessoal e aos arquivos da inteligência? A quem se reportarão (GILL \& PHYTHIAN, 2012, p. 181)?

Todas essas perguntas são cruciais para estabelecer um órgão capaz de verdadeiramente exercer controle, e devem ser cuidadosamente pensadas de acordo com a história e estrutura políticas de cada Estado.

Além de exigir certas definições, o controle da inteligência enfrenta uma série de desafios. Eles incluem, é claro, os desafios normais ao controle de qualquer atividade do Executivo, mas há particularidades da atividade de inteligência que a tornam mais complexa.

Um importante fator é o grande desconhecimento dos parlamentares e seus assessores a respeito das particularidades da atividade. Em geral, as comunidades de inteligência funcionam de forma bastante hermética, e poucas pessoas que jamais passaram por ela entendem seu funcionamento. É raro que um parlamentar chegue a seu cargo com algum conhecimento prévio na área (GONÇALVES, 2010, p. 101).

O conhecimento, contudo, é fundamental para uma supervisão parlamentar eficaz sobre qualquer área do Poder Executivo: quanto mais um órgão supervisor sabe a respeito de uma atividade, melhores serão as perguntas que propõe, melhor será sua capacidade de avaliar performance, e mais eficaz será o controle (ZEGART, 2011). 
Há, ainda, pouco interesse em aprender, já que não é uma ocupação capaz de atrair atenção pública e gerar votos. Conforme resume Peter Gill, "para os políticos envolvidos na supervisão da inteligência, não é possível ganhar votos nessa função - mas é certamente possivel perdê-los" (GILL, 2002). Assim, a maioria dos políticos não se envolve em temas relacionados ao controle da inteligência, exceto em momentos de crise. Os que se envolvem com essa área costumam ter interesse em ocupar cargos, ou vínculos com grupos de interesse relevantes em sua base eleitoral, ou, em pequena proporção, possuem preocupações ou preferências normativas quanto a segurança como bem público (ANTUNES, 2004; CEPIK, 2001, p. 326).

Dentre os desafios, é possível também destacar questões relacionadas à autoridade do legislativo para realizar o controle. Não é incomum que os funcionários da comunidade de inteligência vejam o controle externo com desconfiança. Reduzir a prevalência deste modo de pensar exige promover um treinamento que estimule a confiança no controle externo como uma forma de legitimação, e a estruturação de mecanismos de controle interno eficazes. Esta última medida favorece a sensação de que os parâmetros de controle não são apenas imposições externas (GILL \& PHYTHIAN, 2012, pp. 177, 181).

Estes desafios estão presentes tanto nas antigas quanto nas novas democracias, mas não reduzem a importância da supervisão congressual. Feitas estas observações, em seguida será analisado o controle parlamentar da inteligência dos Estados Unidos, para posterior comparação com o sistema brasileiro.

\subsection{O controle parlamentar da inteligência nos Estados Unidos}

O mecanismo americano de controle parlamentar de inteligência foi estruturado nos anos 1970, e se baseia na existência de dois comitês, um em cada casa do Congresso: o Senate Select Committee on Intelligence e o House 
Permanent Select Committee on Intelligence. Ambas são comissões permanentes e especializadas.

Os comitês devem ser total e imediatamente informados de todas as atividades de inteligência, inclusive de forma antecipada (ANTUNES, 2001, p. 114). O Congresso deve, ainda, aprovar previamente as covert operations (operações clandestinas de inteligência) conduzidas pelas agências americanas. Embora seja um poderoso instrumento de controle, essa aprovação prévia pode reduzir a capacidade do Legislativo de estabelecer críticas em caso de escândalos decorrentes dessas ações (GILL, 2002).

O poder orçamentário, além disso, é uma das principais armas do Congresso americano na supervisão do Executivo. Esse poder é exercido em duas etapas: o Congresso primeiro autoriza uma agência ou programa, e outro atribui os fundos à agência ou programa. A maioria dos comitês do Congresso é responsável apenas pela primeira etapa, e a segunda é realizada por doze subcomitês da Câmara e do Senado. Esse é o caso dos comitês de controle da inteligência, responsáveis apenas pela autorização (ZEGART, 2011).

Embora o controle parlamentar americano seja considerado bem sucedido, há ainda certa dificuldade de estabelecer uma supervisão eficaz da inteligência. No artigo "Congressional Intelligence Oversight: the Electoral Disconnection", Amy Zegart e Julie Quinn apontam quais seriam as maiores dificuldades encontradas pelo Congresso americano ao exercer essa função. Elas argumentam que, embora os mecanismos de supervisão do Legislativo em seu país geralmente sejam considerados robustos, na área da inteligência eles são bem mais frágeis e falhos. Dizem, ainda, que é comum atribuir este quadro apenas à relutância do Executivo em promover maior transparência das agências de inteligência. Embora admitam que este é um fator importante, sua opinião é que grande parte da responsabilidade pelas dificuldades é do próprio Legislativo. 
As autoras relatam que a doutrina americana em geral entende que o bom funcionamento do controle parlamentar seja devido à ideia de electoral connection, a conexão eleitoral. $\mathrm{O}$ cerne deste conceito é que membros do Congresso não precisam ser bem intencionados para promover a fiscalização de agências do governo - basta que queiram se reeleger, e para tanto busquem maximizar os ganhos políticos e minimizar os custos. $\mathrm{O}$ bom funcionamento deste mecanismo, contudo, pressupõe eleitores e grupos de interesse atentos às atividades parlamentares. Assim, áreas que despertam um menor interesse do público, como a inteligência, contam com mecanismos de controle menos eficazes. Os legisladores têm menos incentivo para aprender a lidar com a inteligência, um assunto complexo que gera poucos ganhos políticos (ZEGART \& QUINN, 2010).

\subsection{O controle parlamentar da inteligência no Brasil}

Há vários episódios na história recente do Brasil que ilustram o despreparo e desinteresse do legislativo quanto às atividades de inteligência. A atuação do Poder Legislativo durante a elaboração da Constituição de 1988 foi bastante superficial em relação às atividades de inteligência. Como consequência, as estruturas do SNI permaneceram quase intactas até 1990. O Legislativo perdeu uma chance de interferir na regulamentação e controle do setor, e permaneceu alienado em relação a seu funcionamento (EMÍLIO, 1992, p. 164; ANTUNES, 2001, p. 113).

Mais tarde, durante a elaboração da lei que criou o SISBIN, os parlamentares brasileiros apresentaram poucas propostas relevantes $\mathrm{e}$ praticamente se limitaram a corroborar com a proposta do Poder Executivo. O desinteresse do Legislativo pela área fica claro a partir da data da primeira reunião da CCAI, Comissão de Controle das Atividades de Inteligência: novembro de 2000, um ano após sua criação pela Lei 9.883/1999. Além disso, 
foi marcada apenas em decorrência de escândalos divulgados pela imprensa sobre a atuação da ABIN (ANTUNES, 2004).

Entretanto, a participação do Legislativo é crucial para a legitimidade e eficácia das atividades de inteligência e deve ser buscada. O Congresso brasileiro tem a seu dispor todos os mecanismos constitucionais de controle do Executivo para supervisionar as atividades de inteligência. Nesse âmbito, destacam-se o controle especializado por meio da CCAI.

Devido a seu grande número de componentes, o Legislativo costuma formar comissões especializadas mais restritas, e por isso mais eficazes em seu desempenho (BANDEIRA DE MELLO, 2009, 945). A CCAI é uma comissão permanente mista criada para atuar na área da inteligência. Foi instituída pelo art. $6^{\circ}$ da Lei 9.883/1999:

"Art. 60 O controle e fiscalização externos da atividade de inteligência serão exercidos pelo Poder Legislativo na forma a ser estabelecida em ato do Congresso Nacional.

§ 1o Integrarão o órgão de controle externo da atividade de inteligência os líderes da maioria e da minoria na Câmara dos Deputados e no Senado Federal, assim como os Presidentes das Comissões de Relações Exteriores e Defesa Nacional da Câmara dos Deputados e do Senado Federal.

$\S 20$ O ato a que se refere o caput deste artigo definirá o funcionamento do órgão de controle e a forma de desenvolvimento dos seus trabalhos com vistas ao controle e fiscalização dos atos decorrentes da execução da Política Nacional de Inteligência."

Após a primeira reunião da comissão, os encontros foram poucos e frequentemente adiados por falta de quórum (ANTUNES, 2004). Na segunda reunião, foi aprovado o Projeto de Resolução (PRN) nº 8, de 2001-CN. Em 2008, como o projeto continuava estanque, foi apresentado um novo PRN, de $\mathrm{n}^{\mathrm{o}} 2$, de 2008. Até a aprovação deste projeto em dezembro de 2013, a CCAI atuou sob Regimento provisório elaborado em 2005. O projeto aprovado deu origem à Resolução $n^{\circ}$ 2, de 2013-CN. 
Em seguida, serão destacados alguns aspectos da regulamentação atual da CCAI. Quando pertinente, será traçada uma comparação entre o regimento provisório de 2005 e a Resolução aprovada em 2013. Também serão levados em consideração, como base de comparação, o controle parlamentar da inteligência dos Estados Unidos, as melhores práticas sugeridas pelo DCAF e considerações acerca do tema elaboradas pela doutrina nacional e internacional.

\subsubsection{Mandato do órgão de controle parlamentar}

Em primeiro lugar, a atuação de órgãos parlamentares de controle pode ser classificada quanto a sua abordagem. O manual de melhores práticas do DCAF esclarece que é mais comum que a supervisão parlamentar seja feita através de uma abordagem funcional, responsabilizando apenas um órgão por todo o sistema de inteligência. Essa opção seria mais adequada, uma vez que as várias partes de uma comunidade de inteligência em geral trabalham em conjunto. Seria possível, ainda, adotar uma abordagem institucional, criando órgãos de supervisão diferentes para cada agência (BORN; LEIGH, 2005, p. $80)$.

Desde seu regimento provisório, a CCAI adotou uma abordagem funcional. No regimento atual, essa opção fica clara no art. $2^{\circ}$, que trata do o objetivo principal da CCAI:

"Art. $2^{\circ}$ A atividade da CCAI tem por principal objetivo, entre outros definidos nesta Resolução, a fiscalização e o controle externos das atividades de inteligência e contrainteligência e de outras a elas relacionadas, desenvolvidas no Brasil ou no exterior por órgãos e entidades da Administração Pública Federal, direta ou indireta, especialmente pelos componentes do Sistema Brasileiro de Inteligência (SISBIN), a fim de assegurar que tais atividades sejam realizadas em conformidade com a Constituição Federal e com as normas constantes o ordenamento jurídico nacional, em defesa dos direitos e garantias individuais e do Estado e da sociedade.

$\S 1^{\circ}$ Entende-se por fiscalização e controle, para os fins desta Resolução, todas as ações referentes à supervisão, verificação e inspeção das atividades de pessoas, 
órgãos e entidades relacionados à inteligência e contrainteligência, bem como à salvaguarda de informações sigilosas, visando à defesa do Estado Democrático de Direito e à proteção do Estado e da sociedade.

$\S 2^{\circ} \mathrm{O}$ controle da atividade de inteligência realizado pelo Congresso Nacional compreende as atividades exercidas pelos órgãos componentes do SISBIN em todo o ciclo da inteligência, entre as quais as de reunião, por coleta ou busca, análise de informações, produção de conhecimento, e difusão, bem como a função de contrainteligência e quaisquer operações a elas relacionadas. "

Assim sendo, todo o SISBIN e todas as atividades de inteligência estão sob o controle de um único órgão especializado, a CCAI. Cabe destacar, ainda, que a definição de controle encontrada no $\S 1^{\circ}$, "ações referentes à supervisão, verificação e inspeção”, encontra-se dentro do que a doutrina anglo-saxã consideraria oversight, ou seja, supervisão.

Outra classificação pode ser identificada na forma como os temas sob responsabilidade dos órgãos parlamentares de controle são demarcados. Nesse sentido, o mandato do controle parlamentar pode ser definido de duas formas. Ele pode receber um mandato amplo, com algumas restrições legais quanto a temas que não estão sujeitos a sua investigação, ou pode ser elaborada uma lista detalhada dos assuntos em que pode exercer sua função (BORN; LEIGH, 2005, p. 80). No caso brasileiro, a mesma imprecisão de temas que é característica do conceito nacional de inteligência acaba por ser transmitida ao mandato da CCAI. A comissão, portanto, é dotada de mandato amplo dentro do escopo da inteligência brasileira, e não são estabelecidas limitações a ele na Lei 9.883 ou no Regimento Interno. Nesse caso, a regulamentação brasileira não está exatamente de acordo com a recomendação do DCAF de que o mandato de um órgão de supervisão parlamentar seja claro e específico. Dado o escopo ilimitado da atuação da inteligência brasileira, contudo, parece mais adequado que o controle parlamentar seja igualmente ilimitado.

Outra classificação importante que pode ser realizada quanto ao mandato do controle parlamentar é que ele pode incluir o exame de detalhes operacionais ou pode se limitar a questões de direcionamento político e 
finanças. A primeira opção permite que o órgão de controle tenha mais poder, mas traz um risco decorrente de que ele se envolva demais com as agências de inteligência. Isso poderia inibi-lo de criticar questões operacionais, uma vez que passa também a ser protegido pela barreira do segredo. Por outro lado, sem acesso às operações ele não é capaz de ter ou oferecer ao público a certeza de que a inteligência esteja atuando de acordo com as políticas e parâmetros legais (BORN \& LEIGH, 2005, p. 80).

$\mathrm{O}$ art. $2^{\circ}, \S 3^{\circ}$, e o art. $3^{\circ}$ do Regimento Interno da CCAI estabelecem, respectivamente, suas atribuições e competências. Dentre as atribuições, listadas de forma não excludente, estão os "procedimentos adotados $e$ resultados obtidos" nas atividades de inteligência brasileira, assim como "quaisquer operações de inteligência desenvolvidas por órgãos componentes do SISBIN". Dentre as competências, estão "o controle e a fiscalização externos das atividades de inteligência e contrainteligência, inclusive das operações a elas relacionadas". O mandato da CCAI, portanto, inclui detalhes operacionais.

\subsubsection{Obtenção de informações e documentos}

Os recursos e poderes legais à disposição do órgão parlamentar de supervisão devem ser compatíveis com o seu mandato, e devem permitir acesso irrestrito às informações de que necessite para exercer sua função (BORN \& LEIGH, 2005, p. 80). A CCAI conta com os mesmos mecanismos à disposição das demais comissões. Além disso, a princípio tem acesso a todos os documentos produzidos pela inteligência brasileira, o que lhe permite ultrapassar a barreira do sigilo. Esse é o ponto nevrálgico do controle da inteligência, já que sem acesso irrestrito a documentos sigilosos um órgão de controle está fadado a ser apenas uma fachada democrática. 
Os membros da CCAI tem acesso a arquivos, áreas e instalações dos órgãos do SISBIN, independentemente do seu grau de sigilo (art. $2^{\circ}, \S 4^{\circ}$, do Regimento Interno da CCAI). Para fins de controle, esse acesso é compartilhado por assessores das Consultorias do Senado Federal e da Câmara dos Deputados designados pela Comissão (art. $7^{\circ}, \S 4^{\circ}$, do Regimento Interno da CCAI). As incursões da CCAI em órgãos do SISBIN e o acesso a áreas e instalações devem ser previamente informados aos respectivos órgãos, assim como devem ser acordados os procedimentos para a preservação do sigilo e proteção de áreas e instalações sensíveis $\left(\operatorname{art.} 2^{\circ}, \S 5^{\circ}\right.$, do Regimento Interno da CCAI).

Os artigos 14 e 15 do Regimento Interno da CCAI esclarecem os parâmetros e condições para o acesso dos membros do CCAI, de seus assessores e dos consultores legislativos aos documentos sigilosos. Aos parlamentares que compõem a comissão é atribuído credencial máxima de segurança (grau ultrassecreto), e aos consultores legislativo, assessores e demais servidores que nela atuem é atribuída credencial mínima de segurança (grau secreto). A concessão de credencial de segurança é de competência do Presidente do Congresso Nacional, podendo ser delegada ao Presidente da CCAI. Pode também ser precedida de consultas e pareceres emitidos pelos órgãos competentes do Poder Legislativo e do Poder Executivo.

O DCAF aponta, em sua lista de melhores práticas, que o órgão parlamentar de supervisão deve contar com o poder de iniciar investigações, intimar testemunhas e receber depoimentos. A CCAI tem competência para submeter à Mesa do Senado Federal ou da Câmara dos Deputados pedidos escritos de informações a Ministro de Estado ou titular de órgão diretamente subordinado à Presidência da República, referente à atuação dos órgãos vinculados às suas pastas que atuem nas áreas de inteligência, contrainteligência e na salvaguarda de assuntos sigilosos, observando-se as normas relativas ao manuseio das informações classificadas e à defesa da 
segurança e interesses nacionais (art. 50, $2^{\circ}$, da Constituição Federal, art. $4^{\circ}$ do Regimento Interno da CCAI). A recusa injustificada de prestação das informações requeridas no prazo constitucional implica prática de crime de responsabilidade. Além disso, não é considerada justificativa para a não prestação da informação, no prazo constitucional, a alegação de classificação sigilosa da informação ou de imprescindibilidade do sigilo para a segurança da sociedade e do Estado.

$\mathrm{O}$ art. 10 do Regimento Interno da CCAI estabelece, ainda, duas situações em que a comissão deve obrigatoriamente fazer pedidos de informações. Um relatório parcial sobre as atividades de inteligência desenvolvidas por cada órgão do SISBIN deve ser solicitado ao final do primeiro semestre de cada ano. No final do ano, a comissão deve submeter pedido de um relatório anual consolidado. $\mathrm{O}$ art. 11 do mesmo Regimento estabelece as informações mínimas que devem ser requeridas pela CCAI nestes relatórios.

O relatório semestral foi requerido pela primeira vez no dia 30/04/2014, através do Requerimento $\mathrm{n}^{\circ} 460$ de 2014 . No mesmo mês, a CCAI fez onze requerimentos de informações à $\mathrm{ABIN}$ e ao GSI, fazendo uso de suas prerrogativas $^{11}$. Por meio deles, a comissão buscou obter relatórios sobre as atividades de inteligência e contrainteligência relacionadas: à Copa do Mundo de Futebol, a ser realizada no Brasil em 2014; à imigração de cidadãos estrangeiros no país, especialmente em relação ao fluxo migratório de cidadãos haitianos; à proteção e ao controle das fronteiras brasileiras, tendo em vista, inclusive, as operações Ágata; e à estrutura de contraespionagem brasileira e a estratégia nacional contra a espionagem cibernética. A comissão pediu, ainda, relatório referente à execução finaceiro-orçamentária das atividades de

\footnotetext{
${ }^{11}$ Fonte: $<$ http://www.senado.leg.br/atividade/materia/default.asp>, acesso no dia 12 de setembro de 2014.
} 
inteligência e contrainteligência no ano de 2013, e informações ao Ministro Chefe da Casa Civil sobre o andamento da Política Nacional de Inteligência.

Os demais requerimentos tinham por objetivo a participação do Ministro do GSI e do Diretor-Geral da ABIN em reuniões específicas da CCAI, a fim de apresentar informações sobre diversos temas. A comissão também pode convocar Ministro de Estado ou titular de órgão diretamente subordinado ao Presidente da República para prestar, pessoalmente, informações sobre assuntos relacionados às atividades de inteligência e contrainteligência e à salvaguarda de assuntos sigilosos, importando crime de responsabilidade a ausência sem justificação adequada (art. 50 e art. 58, II, da Constituição Federal e art. $5^{\circ}$ do Regimento Interno da CCAI). Pode, ainda, convidar qualquer autoridade ou cidadão para prestar esclarecimentos sobre assuntos relacionados à atividade de inteligência, contrainteligência ou salvaguarda de informações (art. $6^{\circ}$ do Regimento Interno da CCAI).

Caso a CCAI apure, em processo sigiloso, a prática de ilícitos civis ou penais por parte de pessoas ou órgãos responsáveis pela execução de atividades de inteligência, deve encaminhar suas conclusões ao Ministério Público competente para que este promova a ação de responsabilidade civil ou criminal dos infratores (art. 21 do Regimento Interno da CCAI).

A princípio, a CCAI conta com recursos e poderes compatíveis com a sua função. Uma vez que o Regimento Interno da CCAI é bastante recente, contudo, ainda resta saber como funcionarão de fato, e qual será a atitude dos parlamentares que compõe a comissão perante os desafios do controle da inteligência. A série de requerimentos feitos esse ano, em especial sobre o andamento do PNI, parece ser um desenvolvimento positivo.

\subsubsection{A composição do órgão de supervisão parlamentar}

Para ter legitimidade e comando, é fundamental que os membros do órgão de supervisão parlamentar representem a diversidade partidária do 
Legislativo. Embora seja positivo que tenham experiência prévia na área, é necessário que haja uma clara demarcação da divisão entre órgão de supervisão e comunidade de inteligência. É fundamental, ainda, que os membros sejam civis (BORN \& LEIGH, 2005, p. 81).

$\mathrm{O}$ art. $6^{\circ}$ da Lei 9.883 estabelece que integrarão o órgão de controle externo da atividade de inteligência os líderes da maioria e da minoria na Câmara dos Deputados e no Senado Federal, assim como os Presidentes das Comissões de Relações Exteriores e Defesa Nacional da Câmara dos Deputados e do Senado Federal. Seria formada, portanto, por três deputados e três senadores. No regimento provisório de 2005, a composição da CCAI se limitava a estes seis membros.

A situação, entretanto, gerava dois problemas principais. Em primeiro lugar, a permanência dos parlamentares na comissão era bastante curta. Isso porque, no Senado, o Presidente da CRE tem mandato de dois anos, e na Câmara o Presidente da CREDN tem mandato de um ano. Ademais, as lideranças são trocadas com certa frequência. Dada a complexidade dos assuntos na área de inteligência, uma permanência curta na comissão dificulta que o parlamentar consiga exercer de forma eficaz sua função de controle. A outra questão problemática é que a comissão é composta apenas por lideranças do Congresso, que têm agendas cheias e intensas. Como solução, existiam propostas sugerindo o aumento do número de parlamentares, e sua permanência na comissão ao menos até o final de sua legislatura, com possibilidade de renovação. (GONÇALVES, 2010, p. 186)

O Regimento Interno aprovado em 2013 adotou parcialmente, em seu art. $7^{\circ}$, estas recomendações:

“Art. $7^{\circ}$ A CCAI será composta:

I - pelos Presidentes da Comissão de Relações Exteriores e Defesa Nacional da Câmara dos Deputados e do Senado Federal;

II - pelos Líderes da Maioria e da Minoria, na Câmara dos Deputados e no Senado Federal; 
III - por mais seis parlamentares, com mandato de dois anos, renováveis, nos seguintes termos:

a) um Deputado indicado pela Liderança da Maioria da Câmara dos Deputados;

b) um Deputado indicado pela Liderança da Minoria da Câmara dos Deputados;

c) um Senador indicado pela Liderança da Maioria do Senado Federal;

d) um Senador indicado pela Liderança da Minoria do Senado Federal;

e) um Deputado indicado pela Comissão de Relações Exteriores e Defesa Nacional da Câmara dos Deputados, mediante votação secreta de seus membros;

f) um Senador indicado pela Comissão de Relações Exteriores e Defesa Nacional do Senado Federal, mediante votação secreta de seus membros.

$\S 1^{\circ}$ A Presidência da Comissão será exercida, alternadamente, pelo período de um ano, pelo Presidente da Comissão de Relações Exteriores e Defesa Nacional da Câmara dos Deputados e do Senado Federal.

$\S 2^{\circ}$ A Vice-Presidência da Comissão será exercida pelo Presidente da Comissão de Relações Exteriores e Defesa Nacional da Casa que não ocupar a Presidência.

$\S 3^{\circ}$ Os Presidentes das Comissões de Relações Exteriores e Defesa Nacional e os Lideres da Maioria e da Minoria indicados nos inciso I e II deste artigo poderão ser substituidos por seus respectivos vice-presidentes e vice-líderes, os quais se sujeitarão aos mesmos procedimentos e obrigações relativos à salvaguarda de informações sigilosas previstos nesta Resolução e na forma da Lei."

O número de parlamentares na CCAI foi aumentado de seis para doze, seis membros do Senado e seis da Câmara. Quanto ao número de parlamentares, o manual do DCAF sugere apenas que, para possibilitar uma relação de confiança com a agências que supervisiona, o órgão de supervisão seja relativamente pequeno. Nesse sentido, o art. $7^{\circ}$ parece estar de acordo com a sugestão do DCAF. Se esse número será ou não suficiente, contudo, é questão que só será respondida através de análise do funcionamento da comissão ao longo do tempo.

O centro aconselha, ainda, que o parlamento deve ser responsável por indicar e remover membros de um órgão exercendo supervisão em seu nome. O presidente também deve ser escolhido pelo parlamento ou pela própria comissão. Nesses pontos, a Lei 9.883 e o Regimento Interno vinculam a indicação de metade dos membros à ocupação de cargos externos à comissão. É este também o caso da presidência e da vice-presidência. Essa situação faz com que um dos problemas apontados anteriormente, a participação obrigatória de lideranças extremamente ocupadas, possa se perpetuar. Ao 
menos, no entanto, há agora um número maior de membros, e a metade deles é indicada especialmente para a comissão.

$\mathrm{O}$ art. $7^{\circ}$ do Regimento Interno também fixa o mandato dos parlamentares na CCAI em dois anos, com possibilidade de renovação. Nesse ponto, é interessante destacar que o mandato dos parlamentares americanos nos comitês de controle da inteligência se limita a um tempo máximo de quatro anos. A restrição não está presente nos demais comitês do Congresso americano, nos quais o parlamentar pode permanecer por várias legislaturas seguidas. A regulação diferente no caso dos comitês de controle da inteligência é devida ao temor de que os parlamentares possam ser cooptados por agências de inteligência. Essas agências são extremamente poderosas nos Estados Unidos, e a medida tenta impedir que exerçam sua influência nos comitês. Cria, no entanto, um problema quanto à formação de parlamentares para atuar de forma eficaz numa área extremamente complexa (ZEGART, 2011).

É importante que os órgãos de supervisão parlamentar consigam "fazer as perguntas certas" (ZEGART, 2011). Para os funcionários de uma agência de inteligência é relativamente fácil esconder informações, ainda mais de visitantes que fazem visitas esporádicas e previsíveis. Ademais, estes funcionários frequentemente são preparados para responder exclusivamente as perguntas feitas e nada mais. A grande tarefa, então, é descobrir quais as perguntas que devem ser feitas, e isso exige conhecimento e experiência disponível para os parlamentares e seus assessores (GILL \& PHYTHIAN, 2012, p. 183).

O exemplo americano, embora envolto em contexto bastante diferente, permite identificar dois aspectos que devem ser levados em consideração ao fixar o mandato de parlamentares em órgãos de controle de inteligência. Por um lado, deve ser possível que os membros da comissão acumulem conhecimento sobre as atividades de inteligência; por outro, uma longa permanência nelas poderia favorecer sua cooptação pelas agências que 
supervisionam. Optar por um mandato mais longo, portanto, exige atenção a este último risco.

\subsubsection{Relatórios produzidos pela CCAI}

O DCAF sugere que recomendações e relatórios do órgão de supervisão parlamentar sejam publicadas, debatidas no parlamento, monitoradas quanto a sua implementação pelo governo e pela comunidade de inteligência

Estes órgãos, contudo, devem cuidar para que seus relatórios não incluam material sigiloso. Idealmente, a decisão sobre o que deve ou não ser divulgado deve caber aos próprios parlamentares responsáveis pelo controle, após consulta e negociação com o Executivo (GILL \& PHYTHIAN, 2012, p. $183)$.

O Regimento Interno da CCAI estabelece, em seu art. 12, que a comissão deve produzir relatórios periódicos sobre a fiscalização e o controle das atividades de inteligência e contrainteligência e salvaguarda de assuntos sigilosos desenvolvidas por órgãos e entidades brasileiros. Nestes, deverá constar a quantidade global de recursos alocados e utilizados na execução de atividades de inteligência e contrainteligência, bem como na salvaguarda de assuntos sigilosos. O relatórios de que trata este artigo são considerados secretos.

A CCAI deve, ainda, elaborar relatório anual, nos termos do art. 13 do Regimento Interno:

“Art. 13. A CCAI produzirá relatório anual, de caráter ostensivo, elaborado com base nas informações constantes dos relatórios parcial e geral encaminhados pelos órgãos do SISBIN, dele não podendo constar, sob hipótese alguma:

I - informações que ponham em risco os interesses e a segurança nacionais e da sociedade e do Estado ou que violem a intimidade, a vida privada, a honra e a imagem das pessoas;

II - nomes de pessoas engajadas nas atividades de inteligência, contrainteligência ou salvaguarda de informações; 
III - métodos de inteligência empregados ou fontes de informação em que tais relatórios estão baseados;

IV - o montante de recursos alocados e utilizados especificamente em cada atividade de inteligência, contrainteligência ou de salvaguarda de informações.

$\S 1^{\circ}$ As informações classificadas fornecidas pelos órgãos do SISBIN à CCAI deverão ser preservadas, na forma da Lei, não podendo em hipótese alguma ser desclassificados ou ter sua classificação alterada pela CCAI.

$\S 2^{\circ}$ Caso o CCAI entenda que, por algum motivo, informação classificada por ela recebida de órgão do SISBIN deva ser de conhecimento público, deverá informar ao titular do órgão, cabendo à autoridade competente ou hierarquicamente superior do referido órgão decidir pela desclassificação ou alteração da classificação."

Deste artigo, merece destaque o $\S 2^{\circ}$, que deixa claro que a última palavra em relação à classificação pertence ao Executivo. Essa situação não é de todo incomum no plano internacional. No Reino Unido, por exemplo, o órgão de supervisão do Legislativo envia seu relatório ao Primeiro Ministro, que é responsável por apresentá-lo ao Parlamento e ao público (GILL \& PHYTHIAN, 2012, p. 183).

Não é esta, entretanto, a prática recomendada pelo DCAF. A instituição deixa claro que o Executivo e as agências de inteligência não devem contar com poder de veto em relação ao que é ou não divulgado nos relatórios públicos. Apenas categorias muito limitadas de informações, como a identidade dos agentes, poderiam ser sujeitas a proibição de divulgação. Notase que não é esse o parâmetro adotado no artigo acima, em especial em seu inciso I.

O DCAF sugere que a opinião dos órgãos do Executivo deve ser levada em consideração, mas a decisão final quanto à liberação ou não de informações deve ficar a cargo do parlamento. Quando o veto for permitido, o Executivo e as agências devem ser obrigados por lei a esclarecer de forma genérica o que foi omitido, e porquê. Nesse ponto, portanto, a regulamentação da CCAI está distante das melhores práticas recomendadas pelo DCAF. 


\subsubsection{Apreciação de proposições pela CCAl}

Cabe à CCAI apreciar e emitir parecer, preliminarmente ao exame das demais comissões, todas as proposições que versarem sobre a ABIN e demais órgãos e entidades do SISBIN e sobre as atividades de inteligência e contrainteligência e de salvaguarda de assuntos sigilosos.

\subsubsection{Reuniões da CCAI}

As reuniões da CCAI são secretas e mensais, salvo quando a comissão deliberar o contrário. Em geral, só participarão delas seus membros e servidores credenciados, mas a participação de outros parlamentares e autoridades externas ao Legislativo pode ocorrer mediante requerimento aprovado pela maioria dos membros da comissão.

As atas das reuniões são classificadas como secretas. As comunicações internas e externas da CCAI, suas correspondências e documentos por ela produzidos têm caráter reservado, salvo deliberação em contrário da maioria dos membros.

A dificuldade de manipular documentos secretos sem contar com instalações permanentes e adequadas era uma das críticas feitas ao funcionamento da CCAI antes da aprovação do novo regimento em 2013. Nesse sentido, o Regimento Interno atual dispõe que a CCAI passa a contar com uma sala específica para sua Secretaria no prédio do Congresso Nacional, a qual deve dispor de mecanismos e barreiras para a salvaguarda dos dados sigilosos e proteção ao conhecimento que ali se encontre. A comissão deve ter, ainda, um cofre específico para a guarda de documentos classificados, e, de forma geral, instalações adequadas ao caráter reservado de sua atividade. 


\section{Conclusão}

Num interessante artigo sobre a imagem do controle legislativo em ficções de espionagem, Stan A. Taylor trata da frequente retratação do Congresso como um "intrometido" nas atividades de inteligência. Para o autor, a figura do "intrometido" estaria presente neste tipo de narrativa desde o século XIX. Intrometidos seriam pessoas ou grupos que, propositalmente ou não, interferem na "missão" do herói espião, e apresentam obstáculos ao seu trabalho. Não são necessariamente mal intencionados, e por vezes querem até mesmo ajudá-lo. Entretanto, em sua ignorância quanto às particularidades da espionagem acabam por comprometer a "segurança da nação", ou qualquer que seja o objetivo final da atuação do herói espião. Na ficção contemporânea, os intrometidos são frequentemente os comitês do Legislativo criados para supervisionar as atividades de inteligência (TAYLOR, 2008).

Há vários exemplos dessa tendência, alguns dos quais extremamente populares e recentes - como o filme "Skyfall", do agente ficcional inglês James Bond, e a série de televisão "Homeland", vencedora do Emmy e do Globo de Ouro de melhor série dramática em 2012. No primeiro, a personagem "M", chefe do MI6, enfrenta um parlamento inglês ignorante e hostil. O segundo, em sua terceira temporada, retrata um membro do comitê de supervisão do Senado como um político mais preocupado com seu poder que com a segurança do país; o Congresso, por sua vez, parece estar tentando a todo custo acabar com a CIA.

Os exemplos de ficção acima, dentre outros, exprimem nesse sentido visões conservadoras sobre a atuação da inteligência, segundo as quais o controle externo seria um obstáculo e uma prática prejudicial. O controle, contudo, não deve ser visto como uma prática hostil em relação às pessoas envolvidas com a atividade de inteligência, "mas uma forma de contribuir com 
a internalização de práticas virtuosas e eficientes, assim como de aumentar os graus de eficácia das políticas públicas (ANTUNES, 2004)”.

O controle parlamentar se destaca como mecanismo mais importante de controle em decorrência do papel do Legislativo como representante do povo. Dada a necessidade de sigilo para o desenvolvimento das atividades de inteligência, seu envolvimento é uma forma de permitir, em certa medida, alguma influência da opinião pública.

No Brasil, a aprovação do Regimento Interno da CCAI no final de 2013 representou um avanço quanto a possibilidade de envolvimento do legislativo no controle das atividades de inteligência. Porém, o problema da accountability esse setor mescla-se com outras questões complexas no âmbito da segurança. Em primeiro lugar, a indefinição de mandatos e competências na inteligência brasileira dificulta um controle eficaz. Além disso, a militarização das estruturas estatais de segurança, característica remanescente do regime militar, também se faz presente na inteligência governamental, cuja natureza é, a princípio, civil.

Conforme verificamos, o amplo escopo da inteligência no Brasil e a militarização desta atividade são questões inter-relacionadas. A elaboração da estrutura do SISBIN e da ABIN teve grande influência militar, que ainda hoje se faz presente. A mandato amplo da inteligência é uma das várias questões em sua esfera que remete ao militarismo - em especial, a uma definição de segurança que envolve praticamente toda a vida política do país.

Embora esses sejam obstáculos ao controle da inteligência brasileira, uma atuação consciente do Legislativo, especialmente através da CCAI, poderia auxiliar a superá-los. Em primeiro lugar, a CCAI pode usar de suas prerrogativas legais para cobrar do GSI a aprovação do Plano Nacional de Inteligência. Assim, seria ao menos estabelecida uma priorização das atividades a serem realizadas pelos órgãos da área de inteligência. Ademais, 
poderia buscar iniciar discussões no Congresso Nacional acerca de possíveis reformas na legislação da inteligência brasileira.

O controle das atividades de inteligência é uma questão importante no contexto da busca pela consolidação democrática dos aparatos de segurança do Estado brasileiro. O tema, contudo, em geral recebe pouca atenção no Congresso Nacional, e não parece haver perspectiva de mudança nesse panorama a curto prazo. 


\section{Referências Bibliográficas}

MOREIRA ALVES, Maria Helena. Estado e Oposição no Brasil. $3^{\text {a }}$. ed. Petrópolis: Vozes, 1985.

ANTUNES, Priscila C. Brandão. Controle da Atividade de inteligência no Brasil: legimitidade e eficiência enquanto desafio institucional. Paper apresentado no XXV Congreso da Latin American Studies Association, 2004.

2001.

. SNI \& ABIN : Entre a Teoria e a Prática. Rio de Janeiro: FGV,

BANDEIRA DE MELlO, Celso Antônio. Curso de Direito Administrativo. $26^{\text {a }}$. ed. São Paulo: Malheiros, 2009.

BOBBIO, Norberto. O Futuro da Democracia: Uma defesa das regras do jogo. $6^{\text {a }}$. ed. São Paulo: Paz e Terra, 1997. v. 63.

BOBBIO, N.; MATTEUCI, N.; PASQUINO, G. Dicionário de Política, vol. 1. $11^{a}$ Edição ed. Brasília: Editora UnB, 1998.

BORN, H.; LEIGH, I. Making Intelligence Accountable: Legal Standards and Best Practice for Oversight of Intelligence Agencies. Oslo: Publishing House of the Parliament of Norway, 2005.

BRANDÃO, Priscila Carlos. Serviços Secretos e Democracia no Cone Sul. Niterói: Impetus, 2010.

BRUNEAU, Thomas C.; CRISTIANA, Florina. Intelligence in Developing Democracies: The Quest for Transparency and Effectiveness. In: JOHNSON, L. K. (Org.). The Oxford Handbook of National Security Intelligence. Oxford: Oxford University Press, 2010. .

CEPIK, Marco. Brasil: Legitimidade e Efetividade como Desafios Institucionais. Revista de Ciências Sociais, v. 48, n. 1, p. 67-113, 2005.

. Sistemas Nacionais de Inteligência: Origens, Lógica de Expansão e Configuração Atual.

- Segurança Nacional e Controle Público: Limites dos Mecanismos Institucionais Existentes. Conexão Internacional, v. 23, n. 2, p. 295 - 359, 2001. 
CEPIK, Marco.; ANTUNES, Priscila C. Brandão. The New Brazilian Intelligence Law: An Institucional Assessment. Research and Education in Defense and Security Studies, v. May 22-25, 2001.

DE CARVALHO, Jaílton. Abin se rebela contra o controle militar. $O$ Globo, disponível em $<$ http://oglobo.globo.com/politica/abin-se-rebela-contracontrole-militar-2825300>. Acesso em 11 de setembro de 2014.

DI PIETRO, Maria Sylvia Zanella. Direito Administrativo. 24a . ed. São Paulo: Atlas, 2011.

EMÍLIO, Luís Antônio Bittencourt. O Poder Legislativo e os Serviços Secretos no Brasil. Brasília: Brasília, Faculdades Integradas da Católica de, 1992.

GILL, Peter. Apresentação no Painel "Inteligência, Controle Público e Democracia. Seminário: Atividades de Inteligência no Brasil: Contribuiçoes para a Soberania e a Democracia, 2002.

GILL, Peter.; PHYTHIAN, Mark. Intelligence in an Insecure World. 2a Edição ed. Cambridge: Polity Press, 2012.

GONÇALVES, Joanisval Britto. Atividade de Inteligência e Legislação Correlata. $3^{\text {a }}$ Edição ed. Niterói: Impetus, 2013.

Niterói: Impetus, 2010.

. Políticos e Espiões: O Controle da Atividade de Inteligência.

HERMAN, Michael. Intelligence Power in Peace and War. Cambridge: Cambridge University Press, 1996.

LOWENTHAL, Mark. Intelligence from Secrets to Policy. $5^{\text {a }}$. ed. Washington, D.C.: CQ Press, 2012.

MEIRELLES, Hely Lopes. et al. Direito Administrativo Brasileiro. $36^{\mathrm{a}}$. ed. São Paulo: Malheiros, 2010.

MENDES, Gilmar.; BRANCO, Paulo Gustavo Gonet. Curso de Direito Constitucional. $7^{\text {a }}$. ed. São Paulo: Saraiva, 2012.

MONTEIRO, Tânia. Abin reage a controle militar em carta a Dilma e rejeita ser 'Tropa do Elito'. $O$ Estado de São Paulo, disponível em $<$ http://politica.estadao.com.br/noticias/geral,abin-reage-a-controle-militar-emcarta-a-dilma-e-rejeita-ser-tropa-do-elito,676449>. Acesso em 11 de setembro de 2014. 
SCHULSKY, Abram N.; SMITH, Gary J. Silent Warfare: Understanding the World of Intelligence. $3^{\mathrm{a}}$. ed. Washington, D.C.: Potomac Books, 2002.

TAYLOR, Stan A. The depiction of congressional oversight in spy film and fiction: Is congress the new meddler? Intelligence and National Security, v. 23, n. $1, \quad$ p. 61-80, fev. 2008. Disponível em: $<$ http://www.tandfonline.com/doi/abs/10.1080/02684520701798148>. Acesso em: 5 set. 2014.

UGARTE, José Manuel. El Control Público de la Actividad de Inteligencia : La búsqueda de legitimidad y eficacia . Seminário: Atividades de Inteligência no Brasil: Contribuiçoes para a Soberania e a Democracia, 2002.

. Los Conceptos de Defensa y Seguridad en América Latina: sus Peculiaridades respecto de los vigentes en otras regiones, y las consecuencias políticas de tales peculiaridades. Trabalho apresentado na Lasa,Washigton D.C., 2001.

ZAVERUCHA, Jorge. De FHC a Lula: A Militarização da Agência Brasileira de Inteligência. In: Revista de Sociologia e Política, v. 16, n. 31, p. 177-195, 2008 .

ZEGART, Amy B. Eyes on Spies: Congress and the United States Intelligence Community. Stanford: Hoover Institution Press, 2011 (Kindle Edition).

ZEGART, Amy B.; QUINN, Julie. Congressional Intelligence Oversight: The Electoral Disconnection. Intelligence and National Security. In: Intelligence and National Security, v. 25, n. 6, pp. 744-766, 2010. 